\title{
Synthesis and Characterization of Platinum and
}

\section{Palladium Complexes Featuring a Rare Secondary}

\section{Borane Pincer Motif}

\author{
Angelo Iannetelli, ${ }^{1}$ Graham Tizzard, ${ }^{2}$ Simon J. Coles $^{2}$ and Gareth R. Owen $* 1$ \\ ${ }^{1}$ - School of Applied Sciences, University of South Wales, Pontypridd, CF37 4AT, UK. \\ 2 - UK National Crystallography Service, University of Southampton, Highfield, Southampton.
} SO17 1BJ, UK

\begin{abstract}
The synthesis and characterization of a series of platinum and palladium complexes containing a secondary borane Z-class ligand supported by 2-mercaptopyridine heterocycles is reported herein. Addition of two equivalents of $\mathrm{Na}\left[\mathrm{H}_{2} \mathrm{~B}(\mathrm{mp})_{2}\right]$ to $\left[\mathrm{Pt}(\mu-\mathrm{Cl})\left(\mathrm{COE}^{\mathrm{OMe}}\right)\right]_{2}$ (where $\mathrm{COE}^{\mathrm{OMe}}=8$ methoxycyclooct-4-en-1-ide) in the presence of two equivalents of a tertiary phosphine $\left\{\mathrm{PR}_{3}=\right.$ $\mathrm{PPh}_{3}, \mathrm{PCy}_{3}, \mathrm{PCyp}_{3}, \mathrm{P}(o \text {-tol })_{3}, \mathrm{PPh}_{2}(o$-tol $)$ and $\mathrm{PPh}_{2}$ (2-(3-methyl)indolyl)\} leads to the formation of the complexes $\left[\mathrm{Pt}\left\{\kappa^{3}-S, B, S-\mathrm{HB}\left(\mathrm{mp}_{2}\right\}\left(\mathrm{PR}_{3}\right)\right](\mathbf{1}-\mathbf{6})\right.$. Addition of two equivalents of $\mathrm{Na}\left[\mathrm{H}_{2} \mathrm{~B}(\mathrm{mp})_{2}\right]$ to $\left[\mathrm{Pd}(\mu-\mathrm{Cl})\left(\mathrm{COE}^{\mathrm{OMe}}\right)\right]_{2}$ in the presence of two equivalents of a tertiary phosphine $\left\{\mathrm{PR}_{3}=\mathrm{PPh}_{3}, \mathrm{PCy}_{3}, \mathrm{PCyp}_{3}\right.$, and $\mathrm{PPh}_{2}(o$-tol $\left.)\right\}$ leads to the formation of the complexes $\left[\mathrm{Pd}\left\{\mathrm{\kappa}^{3}-S, B, S-\right.\right.$ $\left.\left.\mathrm{HB}(\mathrm{mp})_{2}\right\}\left(\mathrm{PR}_{3}\right)\right](\mathbf{7}-\mathbf{1 0})$. It was also demonstrated that the synthesis of the palladium complex 7 could be achieved from the palladium precursor, $[\mathrm{PdCl}(\mathrm{Me})(\mathrm{COD})]$ (where $\mathrm{COD}=1,5-$ cyclooctadiene) as an alternative synthetic strategy. In the above reactions, either the $\mathrm{COE}^{\mathrm{OMe}}$
\end{abstract}


fragment or the methyl fragment serve to act as a "hydride acceptor" facilitating the ultimate transformation of the borohydride based ligand, $\left[\mathrm{H}_{2} \mathrm{~B}(\mathrm{mp})_{2}\right]^{-}$to the corresponding secondary borane $\kappa^{3}-S, B, S$ coordinated $\mathrm{HB}(\mathrm{mp})_{2}$ pincer ligand. The complexes $\left[\operatorname{Pd}\left\{\kappa^{3}-S, B, S-\right.\right.$ $\left.\left.\mathrm{HB}(\mathrm{mp})_{2}\right\}\left(\mathrm{PR}_{3}\right)\right]$ and $\left[\mathrm{Pt}\left\{\kappa^{3}-S, B, S-\mathrm{HB}\left(\mathrm{mp}_{2}\right\}\left(\mathrm{PR}_{3}\right)\right]\right.$ are rare examples of metal-borane complexes where one hydrogen substituent remains at the boron center. These compounds have particularly short palladium- and platinum-boron distances, the shortest of the structurally characterized compounds being 2.067(6) $\AA$ for $\left[\operatorname{Pd}\left\{\kappa^{3}-S, B, S-\mathrm{HB}(\mathrm{mp})_{2}\right\}\left(\mathrm{PPh}_{2}(o\right.\right.$-tol $\left.\left.)\right)\right]$ and 2.076(10) $\AA$, for $\left[\operatorname{Pt}\left\{\kappa^{3}-S, B, S-\mathrm{HB}(\mathrm{mp})_{2}\right\}\left(\mathrm{PCy}_{3}\right)\right]$, respectively (the shorter distances of two independent complexes in the unit cells of both structures).

\section{Introduction}

The ubiquitous pincer motif, involving meridional coordination of a tridentate ligand (i.e. a $\kappa^{3}-$ $L, E, L$ coordination mode), is notorious for its ability to furnish highly stable transition metal based catalysts (Figure 1). ${ }^{1}$ As a result pincer-type complexes have been the focus of intense investigation over many years. ${ }^{2}$ There have been a wealth of derivatives featuring a diverse range of donor atoms including phosphorus, ${ }^{3}$ nitrogen,${ }^{4}$ sulfur, ${ }^{5}$ oxygen,${ }^{6}$ carbon ${ }^{7}$ and others ${ }^{8}$ in various combinations. Despite the wide range however, those pincers featuring boron based motifs remain rare and are limited to a handful of examples (Figure 2). ${ }^{3 \mathrm{i}, 9-15}$ Furthermore, whilst there are many examples of pincer ligands where the central unit of the pincer ligand is a secondary group (i.e. where it contains a E-H group), ${ }^{3,4,5 a, b, 6,7 a, b, 8 a}$ there are only few examples featuring a secondary borane as the central unit. ${ }^{3 \mathrm{i}, 12-15}$ We have a particular interest in transition metal complexes containing boron based ligands, specifically those containing borane functionalities where the boron acts as a Z-type ligand. ${ }^{16,17}$ Indeed, several research groups are exploring the propensity of this functional group to act as an acceptor group for a hydrogen atom or other functional groups 
(Scheme 1). ${ }^{16 a}$ The potential for groups to be stored at the boron center opens up the possibility for a mechanism of ligand cooperation in which the ligand is intimately involved in the transformations at the metal center as a means to facilitate catalytic transformations. ${ }^{18}$ Various iterations of ligand cooperation have been established some of which involve the storage of hydrogen atoms, other functional groups and also the storage of dihydrogen upon the ligand. ${ }^{19-21}$ In terms of those transformations at a borane based ligand, Hill was the first to demonstrate that a stored hydride on a borohydride could be delivered to the metal center. ${ }^{22}$ Hill later showed that the process of hydride migration between boron and metal centers was reversible. ${ }^{23,24}$ We later demonstrated that it was possible to cleave dihydrogen as a means of "recharging" a borane functional group with hydrogen to reform a borohydride unit. ${ }^{21 a}$ The Peters' group later carried out some seminal work providing a multitude of examples highlighting the cleavage of dihydrogen and other element-hydrogen bonds across a transition metal-borane species. ${ }^{21 b, 25}$
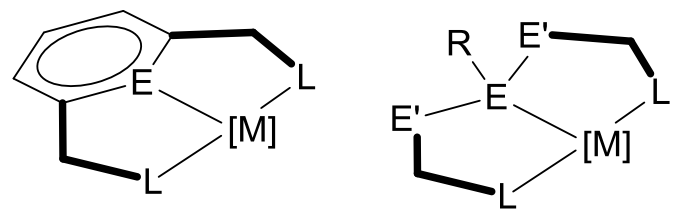

Figure 1 - Highlighting the typical structural features of pincer-type ligands $\left(\kappa^{3}-L, E, L\right)$ containing different donor atoms, $\mathbf{E}$ and $\mathbf{L}$. The structure on the left highlights the ubiquitous pincer structures supported by the substituted phenyl or pyridyl rings while the structure on the right indicates those more diverse pincer ligands $([\mathbf{M}]$ represents a metal center and remaining co-ligands, $\mathbf{E}$ '- $\mathbf{L}$ represents various three atom tethers positioning the central atom within a five membered ring with the metal center). 

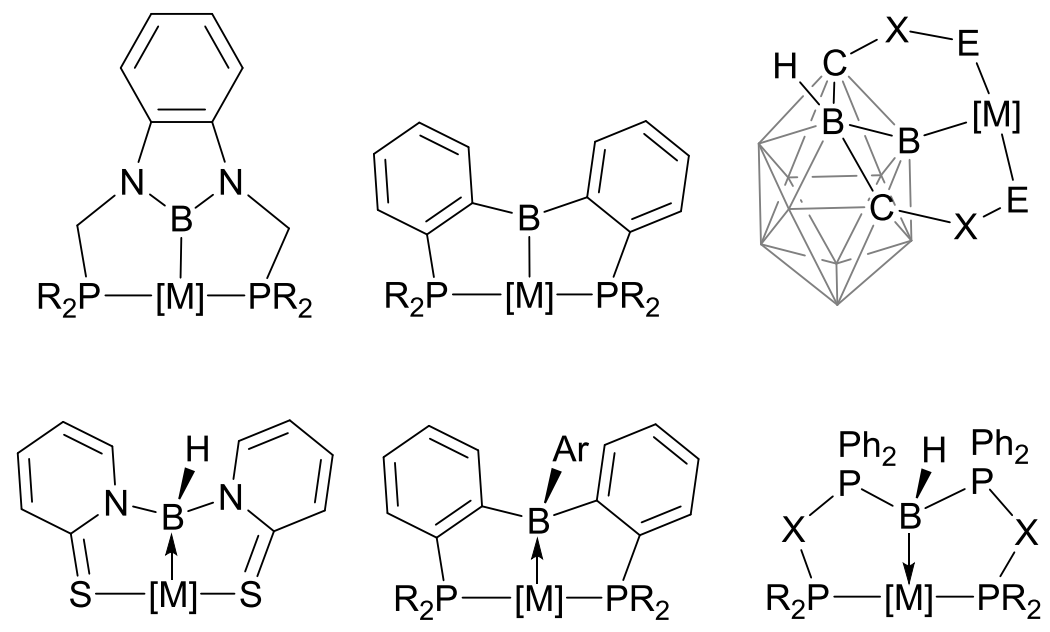

Figure 2 - Highlighting the range of boryl and borane pincer-type ligands $\left(\kappa^{3}-L, B, L\right)$ containing different donor atoms. There are very limited examples of secondary borane pincer complexes.

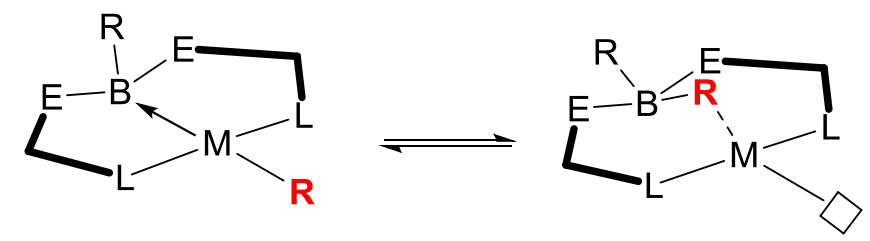

Scheme 1 - The ability of metal bound borane functional groups to act as acceptors for groups such as hydride, alkyl, aryl and other groups leaving an empty coordination site (the red $\mathbf{R}$ represents these various groups).

In 2009, we reported the synthesis of a family of borohydride ligands ${ }^{26 a}$ containing the heterocycle 2-mercaptopyridine (i.e. $\left[\mathrm{HB}(\mathrm{mp})_{3}\right]^{-}$and $\left[\mathrm{H}_{2} \mathrm{~B}(\mathrm{mp})_{2}\right]^{-}$, where $\mathrm{mp}=2$-mercaptopyridyl) and have now reported their coordination to a range of transition metal centers including copper, ${ }^{26 a}$ platinum, ${ }^{14,26 \mathrm{~b}}$ ruthenium, ${ }^{26 \mathrm{c}}$ rhodium $^{26 \mathrm{~d}, \mathrm{e}}$ and palladium. ${ }^{14,26 \mathrm{c}}$ Malik and Panda have reported a series of Group II main group coordination compounds containing these ligands. ${ }^{27 a}$ Some further examples of complexes containing these ligands have been provided by Ghosh albeit via a different strategy. ${ }^{27 b, c}$ We have demonstrated the capacity of this ligand system to deliver hydride to the 
metal center in the case of the rhodium, palladium and platinum complexes with an apparent increased propensity compared to other sulfur based heterocycles. ${ }^{26 \mathrm{~d}}$ Despite a now expansive range of transition metal complexes containing Z-type ligands, there are surprisingly still very few examples of those featuring secondary borane functional groups. ${ }^{3 i, 12-15,26 \mathrm{~d}, 28}$ We therefore wish to report the synthesis and characterization of a number of palladium and platinum pincer complexes containing such functional groups to further expand this range.

\section{Results and Discussion}

As indicated above, the flexible scorpionate ligand, hydrobis(2-mercaptopyridyl)borate (abbreviated as $[\mathbf{B m p}]^{-}$or $\left.\left[\mathrm{H}_{2} \mathrm{~B}(\mathrm{mp})_{2}\right]^{-}\right){ }^{26 a}$ has previously been utilized as a pro-ligand for the secondary borane complexes containing the neutral ligand, $\mathrm{HB}(\mathrm{mp})_{2}{ }^{14,26 \mathrm{~d}}$ Furthermore, the $\mathrm{COE}^{\mathrm{OMe}}\left(\mathrm{COE}^{\mathrm{OMe}}=8\right.$-methoxycyclooct-4-en-1-ide $)$ unit has been used as a means of accepting one of the hydrogen substituents from the borohydride unit. ${ }^{14}$ This reactivity was further explored in an attempt to expand the scope of this reactivity with a range of tertiary phosphine ligands $\left\{\mathrm{PR}_{3}\right.$ $=\mathrm{PPh}_{3}, \mathrm{PCy}_{3}, \mathrm{PCyp}_{3}, \mathrm{P}(o \text {-tol })_{3}, \mathrm{PPh}_{2}(o$-tol $)$ and $\mathrm{PPh}_{2}$ (2-(3-methyl)indolyl) $\}$. Accordingly, two equivalents of a tertiary phosphine were added to a DCM solution of the bimetallic precursor $[\operatorname{Pt}(\mu-$ $\left.\mathrm{Cl})\left(\mathrm{COE}^{\mathrm{OMe}}\right)\right] 2_{2}^{29}$ followed by two equivalents of $\mathrm{Na}[\mathrm{Bmp}]$, in close succession. In all cases, the colourless reaction mixtures instantly became yellow and progressively changed to an orange to red colour depending on the specific phosphine ligand used. The precursor, $\mathrm{Na}[\mathbf{B m p}]$ exhibits limited solubility in the chlorinated solvent, however, it was apparent that the suspended material was consumed over the course of $1-4 \mathrm{~h}$. Aliquots of the reaction mixtures were taken at several points during the course of the reactions. Their ${ }^{31} \mathrm{P}\left\{{ }^{1} \mathrm{H}\right\},{ }^{11} \mathrm{~B}$ and ${ }^{11} \mathrm{~B}\left\{{ }^{1} \mathrm{H}\right\}$ NMR spectra were then recorded. The ${ }^{31} \mathrm{P}\left\{{ }^{1} \mathrm{H}\right\}$ NMR spectra was utilized in order to confirm the coordination of the phosphine ligands to the platinum centers which slowly occurred over time. As a result of its 
limited solubility, it was not possible to determine whether there was any unreacted $\mathrm{Na}$ [Bmp] present within the mixtures by boron NMR (although this was clear from our observations). Nevertheless, the boron spectra provided information regarding the progress of reactivity within the mixtures. The ${ }^{11} \mathrm{~B}\left\{{ }^{1} \mathrm{H}\right\}$ NMR spectra of all reaction mixtures gave two new signals, one at around $7.9 \mathrm{ppm}$ and the second in the region of $14.5 \mathrm{ppm}-17.9 \mathrm{ppm}$ in various ratios depending on the identity of the phosphine ligand. The former signal represented an "intermediate species" (Ptint) which appeared to be common in all reaction mixtures observed within the reaction mixtures in the first $10 \mathrm{~min}$. The length of time the intermediate persisted was dependent on the specific phosphine ligand used. The reactions were considered to have gone to completion when the ${ }^{11} \mathrm{~B}$ NMR showed only the latter species as indicated above. The timescales required for the reaction to reach completion ranged between $1-4 \mathrm{~h}$. At this point the reaction mixtures were filtered and worked up as described in the Experiment Section. The complexes were fully characterised (vide infra) as $\left[\mathrm{Pt}\left\{\kappa^{3}-S, B, S-\mathrm{HB}(\mathrm{mp})_{2}\right\}\left(\mathrm{PR}_{3}\right)\right] ; \mathrm{R}=\mathrm{PPh}_{3}(\mathbf{1}), \mathrm{PCy}_{3}(\mathbf{2}), \mathrm{PCyp}_{3}(\mathbf{3}), \mathrm{P}(o \text {-tol })_{3}(\mathbf{4}), \mathrm{PPh}_{2}(o-$ tol) (5) and $\mathrm{PPh}_{2}$ (2-(3-methyl)indolyl) (6) and where isolated as intense orange to red solids (Scheme 2). The complexes containing the triarylphosphines were orange while those containing the trialkylphosphines were red.

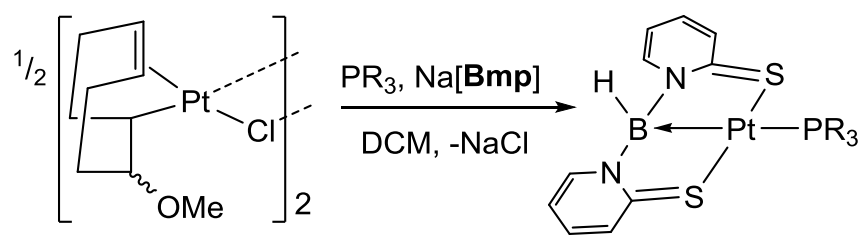

Scheme 2 - Synthesis of $\left[\mathrm{Pt}\left\{\kappa^{3}-S, B, S-\mathrm{BH}(\mathrm{mp})_{2}\right\}\left(\mathrm{PR}_{3}\right)\right], \mathrm{PR}_{3}=\mathrm{PPh}_{3}(\mathbf{1}), \mathrm{PCy}_{3}(\mathbf{2}), \mathrm{PCyp}_{3}(\mathbf{3}), \mathrm{P}(\mathrm{o}-$ tol) $)_{3}$ (4), $\mathrm{PPh}_{2}$ (o-tol) (5) and $\mathrm{PPh}_{2}(2-(3$-methyl)indolyl) (6). This reaction proceeds via an intermediate species, $\mathbf{P t}$ int, and the $\mathrm{COE}^{\mathrm{OMe}}$ unit is lost together with one hydride from the $\mathbf{B m p}$ ligand; see text for details. 
It was of interest to us to confirm the identity of the intermediate species $\mathbf{P} t_{\text {int }}$ within these reactions. We were, of course, able to obtain some evidence for its identity by examining the spectroscopic data of the reaction mixtures. During the course of our investigations, we also found that when $\mathrm{PMe}_{3}$ was used as a potential ligand, $\mathbf{P t}$ int was the only observed species by ${ }^{11} \mathrm{~B}$ NMR spectroscopy. Even when this reaction was left for a number of days there was no indication of the analogous final product to that of the other reactions. There was no spectroscopic evidence that the $\mathrm{PMe}_{3}$ ligand had coordinated to the platinum center. ${ }^{30}$ It appeared as though the phosphine ligand was not involved in the reaction. On the other hand, when the reaction was carried out in the absence of a phosphine ligand, the reaction mixture decomposed within a matter of minutes. Selected spectroscopic data were obtained from the reaction involving $\mathrm{PMe}_{3} .{ }^{31} \mathrm{The}^{11} \mathrm{~B}\left\{{ }^{1} \mathrm{H}\right\} \mathrm{NMR}$ spectrum revealed a peak at $7.9 \mathrm{ppm}$ with platinum satellites, ${ }^{1} \mathrm{~J}_{\mathrm{PtB}}=500 \mathrm{~Hz}$. This value is in the region observed for other platinum-borane (Z-type) complexes ${ }^{266,32}$ confirming that the borohydride unit of the $\left[\mathrm{H}_{2} \mathrm{~B}(\mathrm{mp})_{2}\right]$ ligand has been transformed allowing for a Pt-B interaction. ${ }^{33}$ The corresponding proton NMR spectrum confirmed that one of the hydrogen substituents from the borohydride unit of $\left[\mathrm{H}_{2} \mathrm{~B}(\mathrm{mp})_{2}\right]$ had been transferred to the platinum center, as evidenced by a platinum-hydride signal at $-13.31 \mathrm{ppm}\left({ }^{1} \mathrm{~J}_{\mathrm{PtH}}=1400 \mathrm{~Hz}\right)$. The spectrum also confirmed that the newly formed borane ligand, $\left[\mathrm{HB}(\mathrm{mp})_{2}\right]$, was coordinated to the platinum center where the two $\mathrm{mp}$ rings were in different chemical environments. Finally, the spectrum also confirmed that the $\mathrm{COE}^{\mathrm{OMe}}$ unit was coordinated to the platinum center, in the $\mathbf{P t}$ int species, via one carbon where the double bond was uncoordinated (two signals at 5.60 and $5.86 \mathrm{ppm}$ each integrating to $1 \mathrm{H}$ with no ${ }^{1} \mathrm{~J}_{\mathrm{PtH}}$ coupling between the metal center and the olefinic protons). All of this evidence suggests that the identity of $\mathbf{P t}$ int as $\left[\mathrm{PtH}\left\{\kappa^{3}-S, B, S-\mathrm{HB}(\mathrm{mp})_{2}\right\}\left\{\mathrm{COE}^{\mathrm{OMe}}\right\}\right]$ as shown in Figure $3 .^{34}$ 


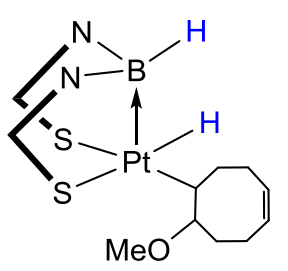

Figure 3 - Postulated structure of $\mathbf{P t}_{\text {int }}$ based on the spectroscopic evidence (N-S represents the mercaptopyridyl supporting units).

A similar methodology was employed to synthesize the corresponding palladium pincer complexes. In a typical reaction, the dimeric precursor $\left[\mathrm{Pd}(\mu-\mathrm{Cl})\left(\mathrm{COE}^{\mathrm{OMe}}\right)\right] 2_{2}^{35}$ was dissolved in DCM to which was added, two equivalents of a phosphine ligand followed by two equivalents of $\mathrm{Na}[\mathbf{B m p}]$. Upon addition of $\mathrm{Na}[\mathbf{B m p}]$, the reaction mixture immediately became orange, deepening over time with the final solutions being brown in colour. As with the platinum reactions, each was monitored by ${ }^{31} \mathrm{P}\left\{{ }^{1} \mathrm{H}\right\},{ }^{11} \mathrm{~B}$ and ${ }^{11} \mathrm{~B}\left\{{ }^{1} \mathrm{H}\right\}$ NMR spectroscopy. These reactions went to completion significantly faster than the platinum based counterparts and so no clear intermediate species was detected by NMR spectroscopy. In all cases, the ${ }^{11} \mathrm{~B}$ NMR spectra revealed only one signal, corresponding to the expected product, within $20 \mathrm{~min}$. Once the reactions were deemed to have gone to completion, the products $\left[\mathrm{Pd}\left\{\kappa^{3}-S, B, S-\mathrm{HB}(\mathrm{mp})_{2}\right\}\left(\mathrm{PR}_{3}\right)\right] ; \mathrm{R}=\mathrm{PPh}_{3}(7), \mathrm{PCy}_{3}(\mathbf{8})$, $\mathrm{PCyp}_{3}$ (9) and $\mathrm{PPh}_{2}(o$-tol) (10) where isolated via a similar workup to that of the platinum complexes.

Within the reactions above, we successfully demonstrated that the $\mathrm{COE}^{\mathrm{OMe}}$ fragment serves as an efficient a hydride acceptor to furnish the secondary borane pincer complexes $\mathbf{1}$ to $\mathbf{1 0}$. We were also interested to see whether other fragments could also be employed. Accordingly, we tested the complexes $[\mathrm{MCl}(\mathrm{Me})(\mathrm{COD})]$ (where $\mathrm{M}=\mathrm{Pt}$ or $\mathrm{Pd}$ ) as alternative metal precursors, expecting that the methyl fragment would provide a means of hydride abstraction from the borohydride ligands. Indeed, this strategy was successful used to synthesis the palladium complex 7 in very high yield 
(Scheme 3). Unfortunately, it could not be utilized to synthesize the platinum complexes since the reactions led to complicated reaction mixtures which did not indicate any signs of the formation of the corresponding pincer complexes. Similar complicated reaction mixtures were found by Crossley when allyl units were utilized as hydride acceptors with platinum complexes. ${ }^{36}$ It appears that the $\mathrm{COE}^{\mathrm{OMe}}$ unit is the only reported species which has been successfully utilized as a hydrogen acceptor in the synthesis of secondary borane platinum complexes.

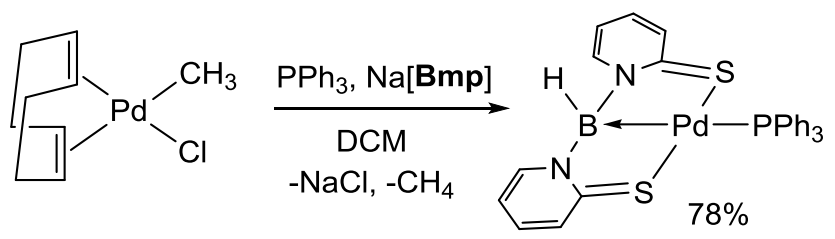

Scheme 3 - Alternative synthesis of $\left[\mathrm{Pd}\left\{\kappa^{3}-S, B, S-\mathrm{BH}(\mathrm{mp})_{2}\right\}\left(\mathrm{PPh}_{3}\right)\right](7)$.

\section{Characterization of Complexes 1 - 10.}

The ten complexes were all fully characterized by NMR spectroscopy, IR spectroscopy and elemental analysis (see experimental section). Selected spectroscopic data have been provided in Table 1 for comparison. For the platinum complexes $\mathbf{1}-\mathbf{6}$, the coordination of the various phosphorus ligands to the platinum center was confirmed by ${ }^{31} \mathrm{P}\left\{{ }^{1} \mathrm{H}\right\}$ NMR spectroscopy which showed a broad single resonance for each case at chemical shifts typical for the specific phosphine coordinated to a platinum center. All signals exhibited ${ }^{1} \mathrm{~J}_{\mathrm{PtP}}$ platinum satellites in the range of 1440 to $1585 \mathrm{~Hz}$. These values and the broadness of the signals are typical of a phosphine ligand trans to a (quadrupolar) boron based ligand. ${ }^{14,26 b, 32}$ The ${ }^{1} \mathrm{H}$ NMR spectra for complexes $\mathbf{1}-\mathbf{6}$ confirmed the absence of the original organic fragment contained in the precursors (i.e. $\mathrm{COE}^{\mathrm{OMe}}$ or $\mathrm{Me}$ ) and confirmed that no transition metal-hydride species had been formed. All spectra confirmed the presence of the two 2-mercaptopyridyl heterocycles within the complex. These protons gave a total integration value of eight compared to the expected number of protons for the corresponding 
phosphine ligand. No other proton environments were apparent in the standard ${ }^{1} \mathrm{H}$ NMR experiments however an additional signal, which integrated for one additional proton, was observed in the corresponding ${ }^{1} \mathrm{H}\left\{{ }^{11} \mathrm{~B}\right\}$ spectra. This corresponds to a B-H unit and confirms that one of the hydrogen substituents of the former anionic $[\mathbf{B m p}]^{-}$ligand had been lost to form a neutral $\left[\mathrm{HB}(\mathrm{mp})_{2}\right]$ ligand. Interestingly, the chemical shift of this $\mathrm{B} H$ proton was found in a very narrow range for the six complexes $(6.52-6.68 \mathrm{ppm})$. Furthermore, these signals also exhibited platinum satellites with $\mathrm{J}_{\mathrm{PtH}}$ coupling constants ranging between $99-118 \mathrm{~Hz}$. These values are lower than have been reported for direct $\mathrm{Pt}-\mathrm{H}-\mathrm{B}$ interactions in which the hydrogen bridges the boron and platinum centers ${ }^{37}$ and are more similar to a ${ }^{2} \mathrm{~J}_{\mathrm{PtH}}$ coupling ${ }^{38,39}$ thereby suggesting a Pt$\mathrm{B}(\mathrm{H})$ connectivity with no direct platinum-hydrogen interactions in any of the complexes $\mathbf{1}-\mathbf{6}$. To the best of our knowledge, there is only two other examples of a nitrogen substituted borane species (either primary or secondary) featuring a $\mathrm{Pt}-\mathrm{B}(\mathrm{H})$ interaction. In the first example the motif is within a macropolyhedral boron-containing cluster making any detail comparison challenging. ${ }^{39}$ Very recently, Neshat and co-workers have reported an octahedral platinum complex featuring a secondary borane complex which was structurally characterized and found to have a facial- $\kappa^{3}-$ $S, B, S$ coordination mode with a very similar ligand in the solid state. ${ }^{12}$ The complex also contained a hydride ligand which was found to reversibly migrate to the boron center (to form the corresponding borohydride species) when placed in solvent. 
Table $1-{ }^{31} \mathrm{P}\left\{{ }^{1} \mathrm{H}\right\},{ }^{11} \mathrm{~B}\left\{{ }^{1} \mathrm{H}\right\}$ NMR and infrared spectroscopic data for pincer complexes containing the $\kappa^{3}-S, B, S-\mathrm{HB}(\mathrm{mp})_{2}$ ligand.

\begin{tabular}{|c|c|c|c|c|c|c|}
\hline Complex & ${ }^{31} \mathrm{P}\left\{{ }^{1} \mathrm{H}\right\}$ & ${ }^{1} \mathrm{~J}_{\mathrm{PtP}}$ & ${ }^{11} \mathrm{~B}\left\{{ }^{1} \mathrm{H}\right\}$ & ${ }^{11} \mathrm{~B}$ & ${ }^{1} \mathrm{H}$ & $\mathrm{IR}(\mathrm{B}-\mathrm{H} \bullet \cdot \mathrm{M})$ \\
& $(\mathrm{ppm})$ & $(\mathrm{Hz})$ & $(\mathrm{ppm})$ & $\mathrm{hhw}^{\mathrm{a}}$ & $\mathrm{B} H$ & power film \\
\hline$\left[\mathrm{Pt}\left\{\mathrm{HB}(\mathrm{mp})_{2}\right\}\left(\mathrm{PPh}_{3}\right)\right]^{\mathrm{b}}(\mathbf{1})$ & 30.3 & 1540 & 15.2 & 480 & 6.68 & 2318 \\
\hline$\left[\mathrm{Pt}\left\{\mathrm{HB}(\mathrm{mp})_{2}\right\}\left(\mathrm{PCy}_{3}\right)\right](\mathbf{2})$ & 36.5 & 1570 & 17.9 & 520 & 6.60 & 2310 \\
\hline$\left[\mathrm{Pt}\left\{\mathrm{HB}(\mathrm{mp})_{2}\right\}\left(\mathrm{PCyp}_{3}\right)\right](\mathbf{3})$ & 37.3 & 1585 & 17.9 & 460 & 6.52 & 2304 \\
\hline$\left[\mathrm{Pt}\left\{\mathrm{HB}(\mathrm{mp})_{2}\right\}\left\{\mathrm{P}(\mathrm{o}-\mathrm{tol})_{3}\right\}\right](\mathbf{4})$ & 27.4 & 1440 & 14.5 & 475 & 6.64 & 2321 \\
\hline$\left[\mathrm{Pt}\left\{\mathrm{HB}(\mathrm{mp})_{2}\right\}\left\{\mathrm{PPh}_{2}(\mathrm{o}-\mathrm{tol})\right\}\right](\mathbf{5})$ & 25.5 & 1485 & 15.6 & 440 & 6.68 & 2323 \\
\hline$\left[\mathrm{Pt}\left\{\mathrm{HB}(\mathrm{mp})_{2}\right\}\left(\mathrm{PPh}_{2}\left({ }^{\mathrm{Me}} \mathrm{In}\right)\right](\mathbf{6})\right.$ & 12.9 & 1497 & 16.4 & 470 & 6.67 & 2318 \\
\hline$\left[\mathrm{Pd}\left\{\mathrm{HB}(\mathrm{mp})_{2}\right\}\left(\mathrm{PPh}_{3}\right)\right]^{\mathrm{b}}(\mathbf{7})$ & 11.2 & & 12.5 & 280 & 5.82 & 2353 \\
\hline$\left[\mathrm{Pd}\left\{\mathrm{HB}(\mathrm{mp})_{2}\right\}\left(\mathrm{PCy}_{3}\right)\right](\mathbf{8})$ & 21.0 & & 14.6 & 300 & 5.67 & 2344 \\
\hline$\left[\mathrm{Pd}\left\{\mathrm{HB}(\mathrm{mp})_{2}\right\}\left(\mathrm{PCyp}_{3}\right)\right](\mathbf{9})$ & 20.3 & & 14.7 & 281 & 5.63 & 2331 \\
\hline $\left.\left.\mathrm{HB}(\mathrm{mp})_{2}\right\}\left\{\mathrm{PPh}_{2}(\mathrm{o}-\mathrm{tol})\right\}\right](\mathbf{1 0})$ & 5.6 & & 13.6 & 300 & 5.81 & 2347 \\
\hline
\end{tabular}

${ }^{\mathrm{a}}$ - hhw is the width of the signal at the half position, ${ }^{\mathrm{b}}$ - from reference 14

Further detail concerning the nature of the $\mathrm{BH}$ interaction with the platinum center was obtained by ${ }^{11} \mathrm{~B}$ NMR spectroscopy. The chemical shifts of the boron nuclei, for complexes $\mathbf{1}-\mathbf{6}$ were located within the range $14.5 \mathrm{ppm}$ to $17.9 \mathrm{ppm}$. This significant downfield shift relative to $\mathrm{Na}$ [Bmp] (-0.9 ppm, MeCN- $\left.\mathrm{d}_{3}\right)$, confirmed the transformation of the borohydride functional group to a metal bound borane functional group. ${ }^{26 a}$ The two complexes containing the trialkylphosphines, exhibited the most downfield chemical shifts, $17.9 \mathrm{ppm}$ for both $\mathrm{PCyp}_{3}$ and 
$\mathrm{PCy}_{3}$. Curiously, this suggests that the more electron donating phosphines provide the most deshielded boron center. Unfortunately in all of the platinum containing complexes, the boron signals were too broad (between $440-520 \mathrm{~Hz}$, in the ${ }^{11} \mathrm{~B}$ NMR spectrum) to obtain ${ }^{1} \mathrm{~J}_{\mathrm{BH}}$ and ${ }^{1} \mathrm{~J}_{\mathrm{PtB}}$ coupling constants. In the case of the ${ }^{1} \mathrm{~J}_{\mathrm{PtB}}$ coupling, this was clearly evident in the line shape of the signals however accurate measurement of the coupling was not possible (see spectra in the ESI). Confirmation that the B-H units contained no significantly interaction with the platinum centers came from the solid state infrared spectra which all revealed a band in the region 2304 $2323 \mathrm{~cm}^{-1}$ characteristic of a terminal B-H stretching mode with little deviation between the complexes. For the palladium complexes $\mathbf{7}-\mathbf{1 0}$, the coordination of the various phosphorus ligands to the palladium center was confirmed by ${ }^{31} \mathrm{P}\left\{{ }^{1} \mathrm{H}\right\}$ NMR spectroscopy. The ${ }^{1} \mathrm{H}$ NMR spectra for complexes $\mathbf{7}-\mathbf{1 0}$ where similar to that those of complexes $\mathbf{1}-\mathbf{6}$ thus confirming the formation of the complexes, $\left[\operatorname{Pd}\left\{\kappa^{3}-S, B, S-B H(m p)_{2}\right\}\left(\mathrm{PR}_{3}\right)\right]\left(\mathrm{PR}_{3}=\mathrm{PPh}_{3}(\mathbf{7}) ; \mathrm{PCy}_{3}(\mathbf{8}) ; \mathrm{PCyp}_{3}(\mathbf{9})\right.$ and $\mathrm{PPh}_{2}(\mathrm{o}-$ tol $\left.)\right\}$ (10). As with the platinum complexes, the $\mathrm{B} H$ proton, was located in the corresponding ${ }^{1} \mathrm{H}\left\{{ }^{11} \mathrm{~B}\right\}$ spectra between $5.63-5.82 \mathrm{ppm}$. In most spectra, this signal was too broad to observe any fine coupling however in the case of $\left[\mathrm{Pd}\left\{\kappa^{3}-S, B, S-\mathrm{BH}(\mathrm{mp})_{2}\right\}\left(\mathrm{PCyp}_{3}\right)\right](\mathbf{9})$ the signal appeared as a doublet with a ${ }^{3} \mathrm{~J}_{\mathrm{PH}}$ coupling constant of $5.9 \mathrm{~Hz}$. The chemical shifts of the boron nuclei, for complexes 7 - $\mathbf{1 0}$ were located within the range $12.5 \mathrm{ppm}$ to $14.7 \mathrm{ppm}$ in the ${ }^{11} \mathrm{~B}$ NMR spectra. These complexes were less stable in $\mathrm{CDCl}_{3}$ solvent than the corresponding platinum complexes. When they were left to stand in this solvent for prolonged periods of time, they slowly started to form the corresponding tris-substituted complexes, $\left[\mathrm{Pd}\left\{\mathrm{\kappa}^{4}-\mathrm{S}, B, S S-\mathrm{B}(\mathrm{mp})_{3}\right\}\left(\mathrm{PR}_{3}\right)\right] .{ }^{14}$ The B-H stretching frequencies of in $\mathbf{7 - 1 0}$ were found between 2331 and $2353 \mathrm{~cm}^{-1}$, again typical of a terminal B-H unit. Finally, elemental analytical data were consistent with the molecular composition of the products $\mathbf{1}-\mathbf{1 0}$. 


\section{Structural characterization of $1,2,3,7,8,9,10$.}

Several crystal structures of the newly synthesized complexes were obtained in order to explore the structural features of the borane pincer complexes in more detail. Crystals suitable for X-ray diffraction of $2,3,8$ and 9 were all obtained by allowing saturated diethyl ether solutions of the complexes stand under an inert atmosphere for several days. Single crystals of $\mathbf{1 0}$ were obtained from a heated saturated solution of the complex in toluene, which was allowed to slowly cool to room temperature. All the crystals obtained from both platinum and palladium complexes were orange in colour. Tables containing a detailed comparison of all structures have been provided within the electronic supporting information. The crystalline material of all complexes, with the exception of complex $\mathbf{8}$, were found to contain two independent complexes within the asymmetric unit. Furthermore, in a number of the structures there was additional disorder over the positions of some of the atoms within the structure. Accordingly, there were up to four sets of bond distances and angles for each complex. Further details concerning the disorder have been provided in the electronic supporting information. All structures confirmed the pincer type coordination mode (i.e. meridional $\left.\kappa^{3}-S, B, S\right)$ of the $\mathrm{HB}(\mathrm{mp})_{2}$ ligand, selected structures are provided in Figures 4 and 5. All seven structures exhibit distorted square-planar geometries around the metal centers with cis inter-ligand angles ranging between $74.7(6)^{\circ}$ to $105.18(7)^{\circ}$ across the complexes. The sum of the four cis-angles about the metal center within each complex ranged from $360.27^{\circ}$ to $365.417^{\circ}$. This relatively narrow range reflects the tendency of the palladium and platinum centers to adopt square planar geometries. The $\mathrm{S}(1)-\mathrm{M}-\mathrm{S}(2)$ angles within the platinum complexes varied from $156.8(4)^{\circ}$ to $162.9(2)^{\circ}$ whilst the same angles in the palladium complexes varied from $155.275(17)^{\circ}$ to 161.9(4) $)^{\circ}$ The boron centers are tetrahedral as expected, with varying degrees of distortion. The sum angles of the three non-hydrogen substitutents lie in the range $326.46^{\circ}$ to $342.57^{\circ}$ (where 
idealised tetrahedral would be $\left.328.5^{\circ}\right)$. The conformation of the binding of the $\mathrm{HB}(\mathrm{mp})_{2}$ ligand is of interest. In most cases, it appears that one of the mercaptopyridyl units is co-planar with the metal-borane vector (as evidenced by the $\mathrm{S}-\mathrm{M}-\mathrm{B}-\mathrm{N}$ torsion angles) while the second mp unit is twisted with a S-M-B-N torsion angle in the region of approximately $40^{\circ}$. The pincer motif in these complexes holds the B-H unit away from the metal center. This is consistent with the spectroscopic evidence described in the characterization section above. The boron center appears to be locked into a specific position, in close proximity to the metal centers, by the two mercaptopyridyl supporting units. This is demonstrated by the fact that the $\operatorname{Pt}(1)-\mathrm{B}(1)$ and $\operatorname{Pd}(1)-$ $\mathrm{B}(1)$ distances are not unaffected, to any significant degree, by the differing trans influences of the various phosphine ligands. The $\operatorname{Pt}(1)-\mathrm{B}(1)$ distances for complexes $\mathbf{1}-\mathbf{3}$ all lie within the narrow range, 2.076(10) - 2.104(10) $\AA$. For complexes 7 - 10, this range is slightly smaller, 2.067(6) 2.094(3) $\AA^{40}{ }^{40}$ These distances are amongst the shortest platinum-borane and palladium-borane distances found on the Cambridge Structural Database (CSD) ${ }^{41}$ This suggests that the HB(mp) 2 ligand has a constrained conformation when it is acting as a pincer ligand. Whilst the borane unit is less affected by the ligand trans to it, its corresponding impact on the phosphine ligands appears to be more significant. For example, the $\operatorname{Pt}(1)-\mathrm{P}(1)$ distances of the structures for complex 2 are 2.349(3) $\AA$ and 2.377(3) $\AA$. These values are much longer than the majority of the crystallographically characterised platinum-tricyclohexylphosphine complexes in the CSD, indicating that the trans influence of the borane unit is high. ${ }^{16,42,43}$ Furthermore, the $\operatorname{Pt}(1)-\mathrm{P}(1)$ distances of the structures for complex 3, 2.3591(5) $\AA$ and 2.3863(5) $\AA$, are also particularly long. With only five reported structures of platinum-tricyclopentylphosphine complexes to date, no clear comparisons can be made however these are significantly longer than any of those reported distances for a Pt-PCyp 3 bond. Similar observations are found for the palladium complexes. For 
example, in the tricyclohexylphosphine complex 8, where the $\mathrm{Pd}(1)-\mathrm{P}(1)$ distance is $2.4662(5) \AA$. Out of the 153 structurally characterised complexes in the CSD, there is only one example of a $\mathrm{Pd}-\mathrm{PCy}_{3}$ distance which is longer than the one found in complex $\mathbf{8}^{44}$

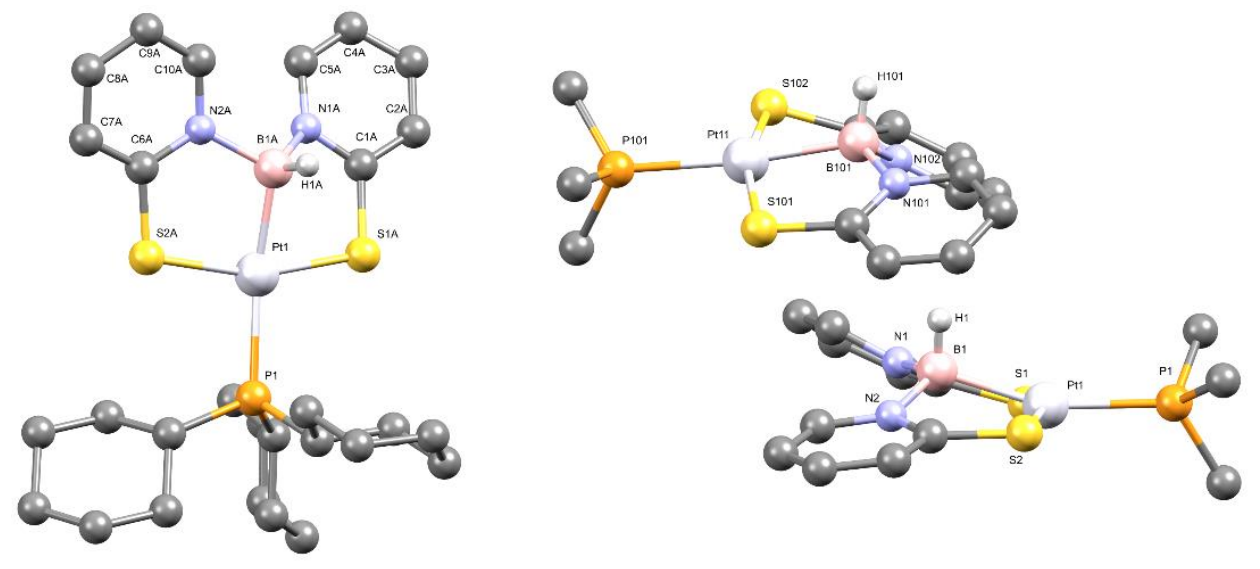

Figure 4 - Crystal structures of platinum complexes 2 and $\mathbf{3}$. One of the two independent molecules in the asymmetric unit is shown for $\left[\mathrm{Pt}\left\{\kappa^{3}-S, B, S-\mathrm{BH}(\mathrm{mp})_{2}\right\}\left(\mathrm{PCy}_{3}\right)\right]$ (2) (left); both molecules in the asymmetric unit are shown for $\left[\mathrm{Pt}\left\{\kappa^{3}-S, B, S-\mathrm{BH}(\mathrm{mp})_{2}\right\}\left(\mathrm{PCp}_{3}\right)\right]$ (3) (right). Hydrogen atoms, with the exception of those on boron, and any component of disorder have been omitted for clarity. For the $\mathrm{PCp}_{3}$ ligands in $\mathbf{3}$ only the $\alpha$-carbons are shown.
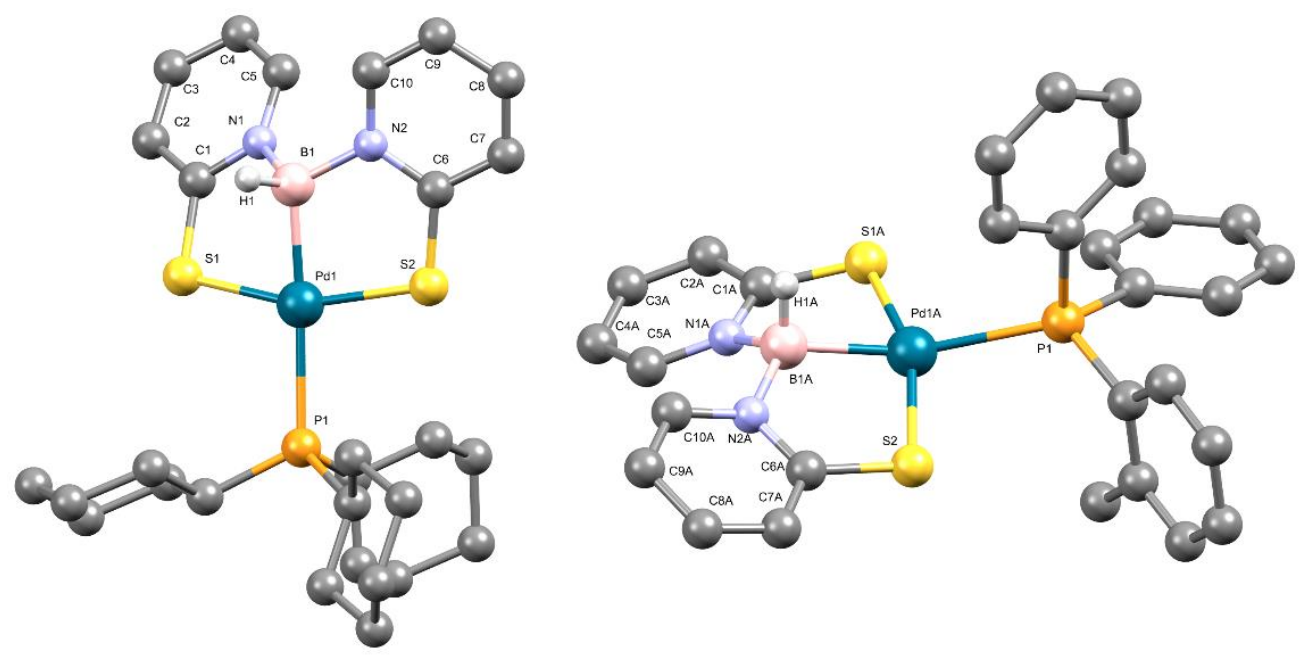
Figure 5 - Crystal structures of palladium complexes 8 and 10 (complex 9 is shown in the supporting information). There was only one independent molecule in the asymmetric unit for $\left[\mathrm{Pd}\left\{\kappa^{3}-S, B, S-\mathrm{BH}(\mathrm{mp})_{2}\right\}\left(\mathrm{PCy}_{3}\right)\right](\mathbf{8})$ (shown on the left); one of the two independent molecules in the asymmetric unit is shown for $\left[\mathrm{Pd}\left\{\kappa^{3}-S, B, S-\mathrm{BH}(\mathrm{mp})_{2}\right\}\left(\mathrm{PPh}_{2}(o\right.\right.$-tol)] (10) (right). Hydrogen atoms, with the exception of those on boron, and any component of disorder have been omitted for clarity.

\section{Further reactivity}

One characteristic of these complexes, that is evident in their NMR spectra, is the lability of the triarylphosphine ligands. In particular, we found that the $\mathrm{P}(\mathrm{o}-\mathrm{tol})_{3}$ ligand dissociated from complex 4 when it was placed in solution (as evidenced by ${ }^{31} \mathrm{P}$ NMR spectroscopy). This is perhaps expected given the apparent large trans influence of the borane functional group (vide supra) ${ }^{43}$ and the large cone angle for $\mathrm{P}(\mathrm{o}-\mathrm{tol}){ }_{3}\left(194^{\circ}\right) .{ }^{45}$ This led us to carry out some test reactions to probe the potential to substitute phosphine ligands. The lability appears to be strongly dependent on the steric properties of the phosphine. The most sterically hindered ligand, $\mathrm{P}(\mathrm{o}-\mathrm{tol})_{3}$ in complex 4 was readily displaced by $\mathrm{PCy}_{3}$ within $10 \mathrm{~min}$ and also by the less electron rich $\mathrm{PPh}_{3}$ in a similar time frame. For complex 2, the sterically bulky $\mathrm{PCy}_{3}\left(170^{\circ}\right)$ ligand was found to be partially displaced by the much weaker donating phosphine, $\mathrm{PPh}_{3}$ although this ligand substitution reaction never went to completion.

Some examples demonstrating the activation of element-element bonds across transition metalborane bonds have been reported. ${ }^{21,25}$ The activation of hydrogen-hydrogen across the platinumborane and palladium-borane bond in complexes $\mathbf{1}$ to $\mathbf{1 0}$ has been investigated. Aside from the lability of the phosphine ligands the complexes, the pincer motif itself appears to be remarkably robust and stable. Toluene- $\mathrm{d}_{8}$ solutions of the complexes were heated to $110^{\circ} \mathrm{C}$ in the presence of 
hydrogen for several days. Periodic analysis of the solutions by NMR showed no indications of $\mathrm{H}_{2}$ activation and very little decomposition. The activation of other element-hydrogen (e.g. C-H, Si$\mathrm{H})$ and element-element bonds is currently under investigation.

\section{Conclusions}

In summary, the synthesis and characterization of a range of platinum and palladium pincers complexes bearing a novel secondary borane central unit has successfully been achieved. The application of the $\mathrm{COE}^{\mathrm{OME}}$ fragment to act as a hydrogen acceptor unit has been expanded further as a generalized procedure. The utilization of the methyl fragment as an alternative methodology has been proven for palladium. Spectroscopic studies have been carried out on the newly formed complexes providing detailed information on the nature of the interaction of the $\mathrm{BH}$ unit with the

metal centers. Furthermore, crystallographic studies reveal that the pincer motif, involving the $\mathrm{HB}(\mathrm{mp})_{2}$ ligand, has very similar features in all complexes. It appears that the borane unit has a high trans influence resulting in a labilisation of the phosphine trans to it within the complexes. Our initial investigations looking at the activation of $\mathrm{E}-\mathrm{H}$ bonds across the $\mathrm{Pt}-\mathrm{B}$ and $\mathrm{Pd}-\mathrm{B}$ bonds in the complexes have thus far been unsuccessful. This has been attributed to the stable pincer motif which is so characteristic of pincer ligands. We are currently exploring this further and are looking at ways in which the meridional coordination mode can be disturbed as a means of promoting reactivity.

\section{Experimental}

General remarks. All manipulations were conducted under inert atmosphere using standard Schlenk line techniques. Solvents were supplied extra dry from Acros Organics and were stored 
over $4 \AA$ molecular sieves. $\mathrm{CDCl}_{3} \mathrm{NMR}$ solvent was stored in a Young’s ampules under $\mathrm{N}_{2}$, over $4 \AA$ molecular sieves and was degassed through three freeze-pump-thaw cycles prior to use. All reagents were used as purchased from commercial sources. The precursors, $\mathrm{Na}\left[\mathrm{H}_{2} \mathrm{~B}(\mathrm{mp})_{2}\right]{ }^{26 \mathrm{a}}$ $\left[\mathrm{Pt}(\mu-\mathrm{Cl})\left(\mathrm{COE}^{\mathrm{OMe}}\right)\right]_{2},{ }^{29}\left[\mathrm{Pd}(\mu-\mathrm{Cl})\left(\mathrm{COE}^{\mathrm{OMe}}\right)\right]_{2},{ }^{35}[\mathrm{PtCl}(\mathrm{Me})(\mathrm{COD})],{ }^{46 \mathrm{a}}[\mathrm{PdCl}(\mathrm{Me})(\mathrm{COD})]^{46 \mathrm{~b}}$ and $\mathrm{PPh}_{2}$ (2-(3-methyl)indolyl ${ }^{47}$ were synthesized according to published methods. All NMR experiments where conducted on a Bruker $400 \mathrm{MHz}$ AscendTM 400 spectrometer. The spectra were referenced internally, to the residual protic solvent $\left({ }^{1} \mathrm{H}\right)$ or the signals of the solvent $\left({ }^{13} \mathrm{C}\right)$. Proton $\left({ }^{1} \mathrm{H}\right)$ and carbon $\left({ }^{13} \mathrm{C}\right)$ assignments were supported by HSQC, HMBC and COSY NMR experiments. In the assignment of the proton NMR spectra the symbol $\tau$ is used to represent an apparent triplet in cases where a doublet of doublet signal is expected. Infrared spectra where recorded on a Perkin-Elmer Spectrum Two ATR FT-IR spectrometer. Mass spectra were recorded by the EPSRC NMSF at Swansea University. Elemental analysis was performed at London Metropolitan University by their elemental analysis service.

Synthesis of $\left[\mathrm{Pt}\left\{\kappa^{3}-S, B, S-H B(m p)_{2}\right\}\left(\mathrm{PCy}_{3}\right)\right]$ (2). A Schlenk flask was charged with $\left[\mathrm{PtCl}\left(\mathrm{COE}^{\mathrm{OMe}}\right)\right]_{2}\left(100 \mathrm{mg}, 1.35 \times 10^{-4} \mathrm{mmol}\right)$ which was subsequently fully dissolved in $30 \mathrm{~mL}$ of DCM. $\mathrm{PCy}_{3}\left(75.7 \mathrm{mg}, 2.70 \times 10^{-4} \mathrm{~mol}\right)$ was added to the solution followed by $\mathrm{Na}[\mathbf{B m p}](69.3$ $\left.\mathrm{mg}, 2.70 \times 10^{-4} \mathrm{~mol}\right)$. The reaction mixture was continuously stirred and allowed to react for 2.5 h. The mixture was then filtered and the volume was reduced to $<1 \mathrm{~mL}$ under reduced pressure. Hexane $(20 \mathrm{~mL})$ was added to the stirring solution to precipitate a small amount of deep orange/ red solid. More solid was precipitated out of solution by reducing the volume of the hexane to approximately $1 \mathrm{~mL}$. The solid product was separated from the remaining solution via cannula filtration before being washed with pentane $(5 \mathrm{~mL})$ and dried under dynamic vacuum. Yield: 91.6 mg, $1.29 \times 10^{-4} \mathrm{~mol}, 48 \% .{ }^{1} \mathrm{H} \mathrm{NMR} \delta\left(\mathrm{CDCl}_{3}\right): 1.26\left(\mathrm{~m}, 3 \mathrm{H},{ }^{\mathrm{Cy}} \mathrm{CH}_{2}\right), 1.27\left(\mathrm{~m}, 6 \mathrm{H},{ }^{\mathrm{Cy}} \mathrm{CH}_{2}\right), 1.52$ 
(m, 6H, $\left.{ }^{\mathrm{Cy}} \mathrm{CH}_{2}\right), 1.69\left(\mathrm{~m}, 3 \mathrm{H},{ }^{\mathrm{Cy} 4} \mathrm{CH}_{2}\right), 1.80\left(\mathrm{~m}, 6 \mathrm{H},{ }^{\mathrm{Cy}} \mathrm{CH}_{2}\right), 2.02\left(\mathrm{~m}, 6 \mathrm{H},{ }^{\mathrm{Cy}} \mathrm{CH}_{2}\right), 2.03(\mathrm{~m}, 3 \mathrm{H}$, $\left.{ }^{\mathrm{Cyl}} \mathrm{CH}\right), 6.70\left(\tau \mathrm{d},{ }^{3} \mathrm{~J}_{\mathrm{HH}}=6.5 \mathrm{~Hz},{ }^{4} \mathrm{~J}_{\mathrm{HH}}=1 \mathrm{~Hz}, 2 \mathrm{H},{ }^{\mathrm{mp}} \mathrm{CH}\right), 7.30\left(\tau \mathrm{d},{ }^{3} \mathrm{~J}_{\mathrm{HH}}=7.6 \mathrm{~Hz}, 2 \mathrm{H},{ }^{\mathrm{mp} 4} \mathrm{CH}\right)$, $7.52\left(\mathrm{~d},{ }^{3} \mathrm{~J}_{\mathrm{HH}}=8.4 \mathrm{~Hz}, 2 \mathrm{H},{ }^{\mathrm{mp} 3} \mathrm{CH}\right), 7.98\left(\mathrm{~d},{ }^{3} \mathrm{~J}_{\mathrm{HH}}=6.1 \mathrm{~Hz}, 2 \mathrm{H},{ }^{\mathrm{mp} 6} \mathrm{CH}\right) .{ }^{1} \mathrm{H}\left\{{ }^{11} \mathrm{~B}\right\} \mathrm{NMR} \delta\left(\mathrm{CDCl}_{3}\right)$ : $6.6\left(\right.$ br. d, $\left.{ }^{2} \mathrm{~J}_{\mathrm{PtH}}=98.9 \mathrm{~Hz}, \mathrm{BH}\right) .{ }^{11} \mathrm{~B} \mathrm{NMR} \delta\left(\mathrm{CDCl}_{3}\right): 17.9$ (s, h.h.w. $\left.=520 \mathrm{~Hz}, \mathrm{BH}\right) .{ }^{11} \mathrm{~B}\left\{{ }^{1} \mathrm{H}\right\} \mathrm{NMR}$ $\delta\left(\mathrm{CDCl}_{3}\right): 17.9$ (s, h.h.w. $\left.=440 \mathrm{~Hz}, \mathrm{BH}\right) .{ }^{31} \mathrm{P}\left\{{ }^{1} \mathrm{H}\right\} \mathrm{NMR} \delta\left(\mathrm{CDCl}_{3}\right): 36.5$ (br. s, ${ }^{1} \mathrm{~J}_{\mathrm{PtP}}=1570 \mathrm{~Hz}$ h.h.w. $=150 \mathrm{~Hz}, \mathrm{PCy}) .{ }^{13} \mathrm{C}\left\{{ }^{1} \mathrm{H}\right\} \operatorname{NMR} \delta\left(\mathrm{CDCl}_{3}\right): 26.7\left(\mathrm{~s},{ }^{\mathrm{Cy}} \mathrm{CH}_{2}\right), 27.7\left(\mathrm{~d}, \mathrm{~J}_{\mathrm{CP}}=10 \mathrm{~Hz},{ }^{\mathrm{Cy}} \mathrm{CH}_{2}\right)$, $30.0\left(\mathrm{~d}, \mathrm{~J}_{\mathrm{CP}}=1.8 \mathrm{~Hz},{ }^{\mathrm{Cy}} \mathrm{CH}_{2}\right), 34.4\left(\mathrm{~d}, \mathrm{~J}_{\mathrm{CP}}=127 \mathrm{~Hz},{ }^{\mathrm{Cy}} \mathrm{CH}\right), 114.5\left(\mathrm{~s},{ }^{\mathrm{mp}}{ }^{5} \mathrm{C}\right), 129.9\left(\mathrm{~s}, \mathrm{~J}_{\mathrm{PtC}}=80.6\right.$ $\left.\mathrm{Hz},{ }^{\mathrm{mp} 3} \mathrm{C}\right), 135.4\left(\mathrm{~s}, \mathrm{~J}_{\mathrm{PtC}}=23 \mathrm{~Hz},{ }^{\mathrm{mp} 4} \mathrm{C}\right), 142.4\left(\mathrm{~d}, \mathrm{~J}_{\mathrm{PtC}}=142 \mathrm{~Hz},{ }^{\mathrm{mp}}{ }^{5} \mathrm{C}\right), 178.6\left(\mathrm{~d},{ }^{3} \mathrm{~J}_{\mathrm{CP}}=19.3 \mathrm{~Hz}\right.$, $\left.{ }^{\mathrm{mp} 2} \mathrm{C}\right) . \mathrm{IR}\left(\mathrm{cm}^{-1}\right.$, ATR powder film) 2922m, 2847m (C-H, $\left.\mathrm{PC}_{6} \mathrm{H}_{11}\right), 2310 \mathrm{w}(\mathrm{B}-\mathrm{H}), 1597 \mathrm{~m}, 1541 \mathrm{~m}$, 1461m, 1418m, 1162m. ESI + MS: m/z 696.22[M - B $]^{+}, 585[\mathrm{M}-\{\mathrm{HB}(\mathrm{mp})\}]^{+}, 281\left[\mathrm{HPCy}_{3}\right]^{+}$. Anal. [Found (calc)] for $\mathrm{C}_{28} \mathrm{H}_{42} \mathrm{BN}_{2} \mathrm{PPtS}_{2}$ : C $47.61 \%$ (47.52\%), H 6.04\% (5.98\%), N 3.93\% $(3.96 \%)$.

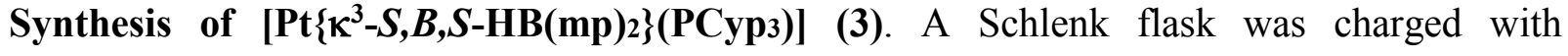
$\left[\mathrm{PtCl}\left(\mathrm{COE}^{\mathrm{OMe}}\right)\right]_{2}\left(100 \mathrm{mg}, 1.35 \times 10^{-4} \mathrm{~mol}\right)$ which was subsequently fully dissolved in $30 \mathrm{~mL}$ of DCM. PCyp $3\left(1.286 \mathrm{~mL}\right.$ of $0.21 \mathrm{M}$ in toluene, $\left.2.70 \times 10^{-4} \mathrm{~mol}\right)$ was added to the solution followed by $\mathrm{Na}[\mathbf{B m p}]\left(69.3 \mathrm{mg}, 2.70 \times 10^{-4} \mathrm{~mol}\right)$. The reaction mixture was continuously stirred and allowed to react for $2.5 \mathrm{~h}$. The mixture was then filtered and the volume was reduced to $<1 \mathrm{~mL}$ under reduced pressure. Hexane $(20 \mathrm{~mL})$ was added to the stirring solution to precipitate a small amount of deep orange/ red solid. More solid was precipitated out of solution by reducing the volume of the hexane to approximately $1 \mathrm{~mL}$. The solid product was separated from the remaining solution via cannula filtration before being washed with pentane $(5 \mathrm{~mL})$ and dried under dynamic vacuum. Yield: $85.3 \mathrm{mg}, 1.28 \times 10^{-4} \mathrm{~mol}, 47 \% .{ }^{1} \mathrm{H}$ NMR $\delta\left(\mathrm{CDCl}_{3}\right): 1.54\left(\mathrm{~m}, 6 \mathrm{H},{ }^{\mathrm{Cyp} 3} \mathrm{CH}_{2}\right), 1.74$

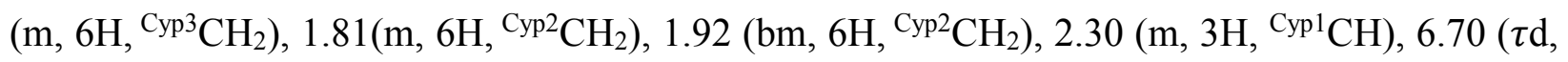


$\left.\mathrm{J}_{\mathrm{HH}}=6.5 \mathrm{~Hz}, 2 \mathrm{H},{ }^{\mathrm{mp} 5} \mathrm{CH}\right), 7.30\left(\tau \mathrm{d}, \mathrm{J}_{\mathrm{HH}}=7.5 \mathrm{~Hz}, 2 \mathrm{H},{ }^{\mathrm{mp} 4} \mathrm{CH}\right), 7.52\left(\mathrm{~d}, \mathrm{~J}_{\mathrm{HH}}=8.5 \mathrm{~Hz}, 2 \mathrm{H},{ }^{\mathrm{mp}} \mathrm{CH}\right)$, $7.97\left(\mathrm{~d}, \mathrm{~J}_{\mathrm{HH}}=6.2 \mathrm{~Hz}, 2 \mathrm{H},{ }^{\mathrm{mp} 6} \mathrm{CH}\right) \cdot{ }^{1} \mathrm{H}\left\{{ }^{11} \mathrm{~B}\right\} \mathrm{NMR} \delta\left(\mathrm{CDCl}_{3}\right): 6.52\left(\mathrm{bs},{ }^{2} \mathrm{~J}_{\mathrm{PtH}}=118 \mathrm{~Hz}\right.$, h.h.w. $=$ $17.3 \mathrm{~Hz}, \mathrm{BH}) .{ }^{11} \mathrm{~B}$ NMR $\delta\left(\mathrm{CDCl}_{3}\right): 17.9$ (s, h.h.w. $\left.=460 \mathrm{~Hz}, \mathrm{BH}\right) .{ }^{11} \mathrm{~B}\left\{{ }^{1} \mathrm{H}\right\} \mathrm{NMR} \delta\left(\mathrm{CDCl}_{3}\right): 17.9$ (s, h.h.w. $=400 \mathrm{~Hz}, \mathrm{BH}) .{ }^{31} \mathrm{P}\left\{{ }^{1} \mathrm{H}\right\}$ NMR $\delta\left(\mathrm{CDCl}_{3}\right): 37.3$ (br. s, ${ }^{1} \mathrm{~J}_{\mathrm{PtP}}=1585 \mathrm{~Hz}$, h.h.w. $=190 \mathrm{~Hz}$ PCyp 3$).{ }^{13} \mathrm{C}\left\{{ }^{1} \mathrm{H}\right\}$ NMR $\delta\left(\mathrm{CDCl}_{3}\right): 26.3\left(\mathrm{~d},{ }^{3} \mathrm{~J}_{\mathrm{CP}}=8.3 \mathrm{~Hz},{ }^{\mathrm{Cyp} 3} \mathrm{C}\right), 30.2\left(\mathrm{~d},{ }^{2} \mathrm{~J}_{\mathrm{CP}}=5.2 \mathrm{~Hz},{ }^{\mathrm{Cyp} 2} \mathrm{C}\right)$, $37.1\left(\mathrm{~d},{ }^{1} \mathrm{~J}_{\mathrm{CP}}=16.2 \mathrm{~Hz},{ }^{2} \mathrm{~J}_{\mathrm{PtC}}=8.7 \mathrm{~Hz},{ }^{\mathrm{Cyp} 1} \mathrm{C}\right), 114.6\left(\mathrm{~s},{ }^{\mathrm{mp}} \mathrm{C}\right), 130.0\left(\mathrm{~s}, \mathrm{~J}_{\mathrm{PtC}}=82 \mathrm{~Hz},{ }^{\mathrm{mp} 3} \mathrm{C}\right), 135.6$ $\left(\mathrm{s}, \mathrm{J}_{\mathrm{PtC}}=23 \mathrm{~Hz},{ }^{\mathrm{mp} 4} \mathrm{C}\right), 142.4\left(\mathrm{~d}, \mathrm{~J}_{\mathrm{PtC}}=30 \mathrm{~Hz},{ }^{\mathrm{mp} 6} \mathrm{C}\right), 178.8\left(\mathrm{~d},{ }^{3} \mathrm{~J}_{\mathrm{CP}}=19.9 \mathrm{~Hz},{ }^{\mathrm{mp} 2} \mathrm{C}\right) . \mathrm{IR}\left(\mathrm{cm}^{-1}\right.$, ATR powder film) 2948m, 2864m, 2304w (B-H), 1599, 1542, 1462, 1416. MS (ESI) ${ }^{+} \mathrm{m} / z$ 654.17 $[\mathrm{M}-\mathrm{B}], 543.16[\mathrm{M}-\{\mathrm{HB}(\mathrm{mp})\}]^{+}, 239.19$ [HPCyp 3$]^{+}$. Anal. [Found (calc)] for $\mathrm{C}_{25} \mathrm{H}_{36} \mathrm{BN}_{2} \mathrm{PPtS}_{2}$ : C $44.96 \%$ (45.12\%), H $5.48 \%$ (5.45\%), N $4.28 \%$ (4.21\%).

Synthesis of $\left[\mathbf{P t}\left\{\boldsymbol{K}^{3}-S, B, S-H B(m p)_{2}\right\}\left(\mathbf{P}(\mathbf{o}-\mathbf{t o l})_{3}\right)\right]$ (4). A Schlenk flask was charged with $\left[\mathrm{PtCl}\left(\mathrm{COE}^{\mathrm{OMe}}\right)\right]_{2}\left(100 \mathrm{mg}, 1.35 \times 10^{-4} \mathrm{~mol}\right)$ which was subsequently fully dissolved in $30 \mathrm{~mL}$ of DCM. $\mathrm{P}(\mathrm{o}-\mathrm{tol})_{3}\left(82.2 \mathrm{mg}, 2.70 \times 10^{-4} \mathrm{~mol}\right)$ was added to the solution followed by $\mathrm{Na}[\mathbf{B m p}](69.3$ $\left.\mathrm{mg}, 2.70 \times 10^{-4} \mathrm{~mol}\right)$. The reaction mixture was continuously stirred and allowed to react for approximately $4 \mathrm{~h}$. The mixture was then filtered and the volume reduced to $<1 \mathrm{~mL}$ under reduced pressure. Hexane $(30 \mathrm{~mL})$ was added to the stirring solution to precipitate a small amount of deep orange/ red solid. More solid was precipitated out of solution by reducing the volume of the hexane to approximately $1 \mathrm{~mL}$. The solid product was separated from the remaining solution via cannula filtration before being washed with hexane $(5 \mathrm{~mL})$ and dried under vacuum. Yield: $102.6 \mathrm{mg}, 1.40$ $\times 10^{-4} \mathrm{~mol}, 52 \% .{ }^{1} \mathrm{H}$ NMR $\delta\left(\mathrm{CDCl}_{3}\right)^{48}: 2.28\left(\mathrm{~s}, 9 \mathrm{H},{ }^{\left({ }^{-} \text {-tol) }\right.} \mathrm{CH}_{3}\right), 6.70\left(\tau \mathrm{d},{ }^{3} \mathrm{~J}_{\mathrm{HH}}=6.6 \mathrm{~Hz},{ }^{4} \mathrm{~J}_{\mathrm{HH}}=1.1\right.$ $\mathrm{Hz}, 2 \mathrm{H},{ }^{\mathrm{mp}} \mathrm{CH}$ ), 7.20 (unresolved, $3 \mathrm{H},{ }^{(0-\text { tol) }} \mathrm{CH}$ ), 7.26 (unresolved, $2 \mathrm{H},{ }^{\mathrm{mp} 4} \mathrm{CH}$ ), 7.29 (unresolved, $\left.6 \mathrm{H},{ }^{(\mathrm{o}-\mathrm{tol})} \mathrm{CH}\right), 7.40\left(\mathrm{~d},{ }^{3} \mathrm{~J}_{\mathrm{HH}}=8.5 \mathrm{~Hz}, 2 \mathrm{H},{ }^{\mathrm{mp} 3} \mathrm{CH}\right), 7.77\left(\mathrm{t}, 3 \mathrm{H},{ }^{(\mathrm{o}-\mathrm{tol})} \mathrm{CH}\right), 7.92\left(\mathrm{~d},{ }^{3} \mathrm{~J}_{\mathrm{HH}}=6.2 \mathrm{~Hz}, 2 \mathrm{H}\right.$, $\left.{ }^{\mathrm{mp}}{ }^{6} \mathrm{CH}\right) .{ }^{1} \mathrm{H}\left\{{ }^{11} \mathrm{~B}\right\} \mathrm{NMR} \delta\left(\mathrm{CDCl}_{3}\right): 6.64\left(\mathrm{~s},{ }^{2} \mathrm{~J}_{\mathrm{PtH}}=114 \mathrm{~Hz}, \mathrm{BH}\right) .{ }^{11} \mathrm{~B} \mathrm{NMR} \delta\left(\mathrm{CDCl}_{3}\right): 14.5(\mathrm{~s}$, 
h.h.w. $=475 \mathrm{~Hz}, \mathrm{BH}) .{ }^{11} \mathrm{~B}\left\{{ }^{1} \mathrm{H}\right\} \mathrm{NMR} \delta\left(\mathrm{CDCl}_{3}\right)$ : 14.5 (s, h.h.w. $\left.=435 \mathrm{~Hz}, \mathrm{BH}\right) .{ }^{31} \mathrm{P}\left\{{ }^{1} \mathrm{H}\right\} \mathrm{NMR} \delta$ $\left(\mathrm{CDCl}_{3}\right): 27.4$ (br. s, ${ }^{1} \mathrm{~J}_{\mathrm{PtP}}=1440 \mathrm{~Hz}$, h.h.w. $\left.=170 \mathrm{~Hz}, \mathrm{P}(\mathrm{o}-\mathrm{tol})_{3}\right) \cdot{ }^{13} \mathrm{C}\left\{{ }^{1} \mathrm{H}\right\} \mathrm{NMR} \delta\left(\mathrm{CDCl}_{3}\right): 23.4$ $\left(\mathrm{d},{ }^{3} \mathrm{~J}_{\mathrm{CP}}=7 \mathrm{~Hz},{ }^{\left({ }^{\text {o-tol }}\right)} \mathrm{CH}_{3}\right), 114.7\left(\mathrm{~s},{ }^{\mathrm{mp}} \mathrm{C}\right), 125.6\left(\mathrm{~d}, \mathrm{~J}_{\mathrm{CP}}=9.4 \mathrm{~Hz},{ }^{\left({ }^{(0-t o l}\right)} \mathrm{C}\right), 129.7\left(\mathrm{~s},{ }^{(\text {o-tol) }} \mathrm{C}\right), 130.1$ $\left(\mathrm{s},{ }^{\mathrm{mp} 3} \mathrm{C}\right), 131.0\left(\mathrm{~d}, \mathrm{~J}_{\mathrm{CP}}=28 \mathrm{~Hz},{ }^{\left({ }^{-\mathrm{tol})}\right)} \mathrm{C}\right), 131.6\left(\mathrm{~d}, \mathrm{~J}_{\mathrm{CP}}=6.1 \mathrm{~Hz},{ }^{\left({ }^{o-t o l}\right)} \mathrm{C}\right), 135.1\left(\mathrm{~d}, \mathrm{~J}_{\mathrm{CP}}=14.5 \mathrm{~Hz},{ }^{(0-}\right.$ $\left.{ }^{\mathrm{tol})} \mathrm{C}\right), 135.5\left(\mathrm{~s}, \mathrm{~J}_{\mathrm{PtC}}=23.2 \mathrm{~Hz},{ }^{\mathrm{mp} 4} \mathrm{C}\right), 142.2\left(\mathrm{~d}, \mathrm{~J}_{\mathrm{PtC}}=31.8 \mathrm{~Hz},{ }^{\mathrm{mp} 6} \mathrm{C}\right), 143.2\left(\mathrm{~d}, \mathrm{~J}_{\mathrm{CP}}=9.9 \mathrm{~Hz},{ }^{(0-}\right.$ $\left.{ }^{\text {tol) }} \mathrm{C}\right), 178.8\left(\mathrm{~d},{ }^{3} \mathrm{~J}_{\mathrm{CP}}=20.5 \mathrm{~Hz},{ }^{\mathrm{mp} 2} \mathrm{C}\right) . \mathrm{IR}\left(\mathrm{cm}^{-1}\right.$, ATR powder film) $2321 \mathrm{w}(\mathrm{B}-\mathrm{H}), 1603,1541$, 1462. MS (ESI) ${ }^{+}: m / z 720.12$ [M - B]. Anal. [Found (calc)] for $\mathrm{C}_{31} \mathrm{H}_{30} \mathrm{BN}_{2} \mathrm{PPtS}_{2}$ : C $51.15 \%$ (50.90\%), H 3.96\% (4.13\%), N 3.94\% (3.83\%).

Synthesis of $\left[\mathrm{Pt}\left\{\mathrm{K}^{3}-\mathrm{S}, \boldsymbol{B}, \boldsymbol{S}-\mathrm{HB}(\mathrm{mp})_{2}\right\}\left(\mathrm{PPh}_{2}(\mathrm{o}-\mathrm{tol})\right)\right]$ (5). A Schlenk flask was charged with $\left[\mathrm{PtCl}\left(\mathrm{COE}^{\mathrm{OMe}}\right)\right]_{2}\left(100 \mathrm{mg}, 1.35 \times 10^{-4} \mathrm{~mol}\right)$ which was subsequently fully dissolved in $30 \mathrm{~mL}$ of DCM. $\mathrm{Ph}_{2} \mathrm{P}(\mathrm{o}-$ tol $)\left(74.6 \mathrm{mg}, 2.70 \times 10^{-4} \mathrm{~mol}\right)$ was added to the solution followed by $\mathrm{Na}[\mathbf{B m p}]$ $\left(69.3 \mathrm{mg}, 2.70 \times 10^{-4} \mathrm{~mol}\right)$. The reaction mixture was continuously stirred and allowed to react for $3 \mathrm{~h}$. The mixture was then filtered and the volume was reduced to $<1 \mathrm{~mL}$ under reduced pressure. Hexane $(20 \mathrm{~mL})$ was added to the stirring solution to precipitate an orange solid. The solid product was separated from the remaining solution via cannula filtration before being washed with additional hexane ( $5 \mathrm{~mL}$ ) and dried under dynamic vacuum. Yield: $93.5 \mathrm{mg}, 1.33 \times 10^{-4} \mathrm{~mol}, 49 \%$. ${ }^{1} \mathrm{H} \mathrm{NMR} \delta\left(\mathrm{CDCl}_{3}\right)^{48}: 2.54\left(\mathrm{~s}, 3 \mathrm{H},{ }^{(0-\mathrm{tol})} \mathrm{CH}_{3}\right), 6.74\left(\tau \mathrm{d},{ }^{3} \mathrm{~J}_{\mathrm{HH}}=6.6 \mathrm{~Hz},{ }^{4} \mathrm{~J}_{\mathrm{HH}}=1.0 \mathrm{~Hz}, 2 \mathrm{H},{ }^{\mathrm{mp}} \mathrm{CH}\right)$, $6.80\left(\mathrm{t}, 1 \mathrm{H},{ }^{(0-\text { tol }) 5} \mathrm{CH}\right), 7.12\left(\mathrm{t}, 1 \mathrm{H},{ }^{(0-\text { tol }) 4} \mathrm{CH}\right), 7.27$ (unresolved, $\left.1 \mathrm{H},{ }^{(0-\text { tol }) 3} \mathrm{CH}\right), 7.27$ (unresolved, $\left.1 \mathrm{H},{ }^{(0-\mathrm{tol}) 6} \mathrm{CH}\right), 7.30\left(\tau \mathrm{d},{ }^{3} \mathrm{~J}_{\mathrm{HH}}=7.4 \mathrm{~Hz}, 2 \mathrm{H},{ }^{\mathrm{mp} 4} \mathrm{CH}\right), 7.37\left(\mathrm{~m}, 4 \mathrm{H},{ }^{m-\mathrm{Ph}} \mathrm{CH}\right), 7.38\left(\mathrm{~m}, 2 \mathrm{H},{ }^{p-\mathrm{Ph}} \mathrm{CH}\right)$, $7.48\left(\mathrm{~d},{ }^{3} \mathrm{~J}_{\mathrm{HH}}=8.5 \mathrm{~Hz}, 2 \mathrm{H},{ }^{\mathrm{mp} 3} \mathrm{CH}\right), 7.68\left(\mathrm{~m}, 4 \mathrm{H},{ }^{o-\mathrm{Ph}} \mathrm{CH}\right), 7.96\left(\mathrm{~d},{ }^{3} \mathrm{~J}_{\mathrm{HH}}=6.2 \mathrm{~Hz}, 2 \mathrm{H},{ }^{\mathrm{mp} 6} \mathrm{CH}\right)$. ${ }^{1} \mathrm{H}\left\{{ }^{11} \mathrm{~B}\right\} \mathrm{NMR} \delta\left(\mathrm{CDCl}_{3}\right): 6.68\left(\mathrm{~s},{ }^{2} \mathrm{~J}_{\mathrm{PtH}}=118 \mathrm{~Hz}, \mathrm{BH}\right) .{ }^{11} \mathrm{~B} \mathrm{NMR} \delta\left(\mathrm{CDCl}_{3}\right): 15.6$ (br. s, h.h.w. $=$ $440 \mathrm{~Hz}, \mathrm{BH}) .{ }^{11} \mathrm{~B}\left\{{ }^{1} \mathrm{H}\right\}$ NMR $\delta\left(\mathrm{CDCl}_{3}\right): 15.6$ (br. s, h.h.w. $\left.=400 \mathrm{~Hz}, \mathrm{BH}\right) \cdot{ }^{31} \mathrm{P}\left\{{ }^{1} \mathrm{H}\right\}$ NMR $\delta$ $\left(\mathrm{CDCl}_{3}\right): 25.5$ (br. s, ${ }^{1} \mathrm{JPtP}_{\mathrm{P}}=1485 \mathrm{~Hz}$, h.h.w. $=147 \mathrm{~Hz}, \mathrm{Ph} 2 \mathrm{P}(\mathrm{o}$-tol $\left.)\right) .{ }^{13} \mathrm{C}\left\{{ }^{1} \mathrm{H}\right\} \mathrm{NMR} \delta\left(\mathrm{CDCl}_{3}\right)$ : 
$23.3\left(\mathrm{~d},{ }^{3} \mathrm{~J}_{\mathrm{CP}}=10.8 \mathrm{~Hz},{ }^{\left({ }^{-} \text {-ol }\right)} \mathrm{CH}_{3}\right), 115.0\left(\mathrm{~s},{ }^{\mathrm{mp}}{ }^{5} \mathrm{C}\right), 125.4\left(\mathrm{~d},{ }^{4} \mathrm{~J}_{\mathrm{CP}}=5.9 \mathrm{~Hz},{ }^{(0-\mathrm{olol})}{ }^{4} \mathrm{C}\right), 128.5\left(\mathrm{~d},{ }^{4} \mathrm{~J}_{\mathrm{CP}}\right.$ $\left.=9.1 \mathrm{~Hz},{ }^{p-\mathrm{Ph}} \mathrm{C}\right), 129.5\left(\mathrm{~s},{ }^{(\mathrm{o}-\mathrm{tol}) 6} \mathrm{C}\right), 129.7\left(\mathrm{~s},{ }^{m-\mathrm{Ph}} \mathrm{C}\right), 130.1\left(\mathrm{~s},{ }^{\mathrm{mp} 3} \mathrm{C}\right), 131.0\left(\mathrm{~d},{ }^{3} \mathrm{~J}_{\mathrm{CP}}=6.6 \mathrm{~Hz},{ }^{\left({ }^{\circ}-\right.}\right.$ $\left.{ }^{\text {toll) } 3} \mathrm{C}\right), 132.9\left(\mathrm{~d},{ }^{3} \mathrm{~J}_{\mathrm{CP}}=5.7 \mathrm{~Hz},{ }^{(0-\text { tol }) 5} \mathrm{C}\right), 133.5\left(\mathrm{~d},{ }^{1} \mathrm{~J}_{\mathrm{CP}}=30.4 \mathrm{~Hz},{ }^{(\mathrm{o}-\mathrm{tol}) 2} \mathrm{C}\right), 134.5\left(\mathrm{~d},{ }^{i-\mathrm{Ph}} \mathrm{C}\right), 134.7$ $\left(\mathrm{d},{ }^{2} \mathrm{~J}_{\mathrm{CP}}=13.7 \mathrm{~Hz},{ }^{o-\mathrm{Ph}} \mathrm{C}\right), 135.8\left(\mathrm{~s}, \mathrm{~J}_{\mathrm{PtC}}=22.7 \mathrm{~Hz},{ }^{\mathrm{mp} 4} \mathrm{C}\right), 142.3\left(\mathrm{~d}, \mathrm{~J}_{\mathrm{PtC}}=27.6 \mathrm{~Hz},{ }^{\mathrm{mp} 6} \mathrm{C}\right), 142.4(\mathrm{~d}$, $\left.{ }^{(\text {o-tol) } 1} \mathrm{C}\right), 178.6\left(\mathrm{~d},{ }^{3} \mathrm{~J}_{\mathrm{CP}}=20.6 \mathrm{~Hz},{ }^{\mathrm{mp}} \mathrm{C}\right) . \mathrm{IR}\left(\mathrm{cm}^{-1}\right.$, ATR powder film) $2323 \mathrm{w}(\mathrm{B}-\mathrm{H}) . \mathrm{MS}(\mathrm{ESI})^{+}$: $m / z \quad 692.09 \quad[\mathrm{M}-\mathrm{B}], \quad 581.08 \quad[\mathrm{M}-\{\mathrm{HB}(\mathrm{mp})\}]^{+}$. Anal. [Found (calc) $]$for $\mathrm{C}_{29} \mathrm{H}_{26} \mathrm{BN}_{2} \mathrm{PPtS}_{2} \bullet / 3 \mathrm{CH}_{2} \mathrm{Cl}_{2}: \mathrm{C} 46.85 \%$ (46.89\%), $\mathrm{H} 3.65 \%$ (3.60\%), N 4.06\% (3.69\%).

Synthesis of $\left[\mathbf{P t}\left\{\boldsymbol{K}^{3}-S, B, S-H B(m p)_{2}\right\}\left(\mathbf{P P h}_{2}\left({ }^{\mathrm{Me}} \mathrm{In}\right)\right)\right.$ (6). A Schlenk flask was charged with $\left[\mathrm{PtCl}\left(\mathrm{COE}^{\mathrm{OMe}}\right)\right]_{2}\left(100 \mathrm{mg}, 1.35 \times 10^{-4} \mathrm{~mol}\right)$ which was subsequently fully dissolved in $30 \mathrm{~mL}$ of DCM. $\mathrm{Ph}_{2} \mathrm{P}\left({ }^{\mathrm{Me}} \mathrm{In}\right)\left(85.2 \mathrm{mg}, 2.70 \times 10^{-4} \mathrm{~mol}\right)$ was added to the solution followed by $\mathrm{Na}[\mathbf{B m p}]$ $\left(69.3 \mathrm{mg}, 2.70 \times 10^{-4} \mathrm{~mol}\right)$. The reaction mixture was continuously stirred and allowed to react for $3 \mathrm{~h}$. The mixture was then filtered and the volume was reduced to $<1 \mathrm{~mL}$ under reduced pressure. Hexane $(20 \mathrm{~mL})$ was added to the stirring solution to precipitate an orange solid. The solid product was separated from the remaining solution via cannula filtration before being washed with additional hexane $(5 \mathrm{~mL})$ and dried under dynamic vacuum. Yield: $130.8 \mathrm{mg}, 1.76 \times 10^{-4} \mathrm{~mol}$, $65 \% .{ }^{1} \mathrm{H} \mathrm{NMR} \delta\left(\mathrm{CDCl}_{3}\right)^{48}: 1.99\left(\mathrm{~s}, 3 \mathrm{H}, \mathrm{CH}_{3}\right), 6.79\left(\tau \mathrm{d},{ }^{3} \mathrm{~J}_{\mathrm{HH}}=6.4 \mathrm{~Hz},{ }^{4} \mathrm{~J}_{\mathrm{HH}}=1.0 \mathrm{~Hz}, 2 \mathrm{H},{ }^{\mathrm{mp} 5} \mathrm{CH}\right)$, $7.10\left(\mathrm{t}, 1 \mathrm{H},{ }^{\mathrm{In}} \mathrm{CH}\right.$ ), $7.20\left(\mathrm{t}, 1 \mathrm{H},{ }^{\mathrm{In}} \mathrm{CH}\right.$ ), 7.35 (unresolved, $2 \mathrm{H},{ }^{\mathrm{mp}} \mathrm{CH}^{4}$ ), 7.35 (unresolved, $1 \mathrm{H},{ }^{\mathrm{In}} \mathrm{CH}$ ), 7.38 (unresolved, $4 \mathrm{H},{ }^{\mathrm{Ph}} \mathrm{CH}$ ), 7.41 (unresolved, $2 \mathrm{H},{ }^{\mathrm{Ph}} \mathrm{CH}$ ), 7.58 (unresolved, $1 \mathrm{H},{ }^{\mathrm{In}} \mathrm{CH}$ ), $7.51(\mathrm{~d}$, $\left.{ }^{3} \mathrm{~J}_{\mathrm{HH}}=8.5 \mathrm{~Hz}, 2 \mathrm{H},{ }^{\mathrm{mp} 3} \mathrm{CH}\right), 7.60\left(\mathrm{~m}, 4 \mathrm{H},{ }^{o-\mathrm{Ph}} \mathrm{CH}\right), 7.99\left(\mathrm{~d},{ }^{3} \mathrm{~J}_{\mathrm{HH}}=6.2 \mathrm{~Hz}, 2 \mathrm{H},{ }^{\mathrm{mp} 6} \mathrm{CH}\right), 9.11(\mathrm{~s}, 1 \mathrm{H}$, $\left.{ }^{\mathrm{In}} \mathrm{NH}\right) .{ }^{1} \mathrm{H}\left\{{ }^{11} \mathrm{~B}\right\} \mathrm{NMR} \delta\left(\mathrm{CDCl}_{3}\right): 6.67(\mathrm{~s}, \mathrm{BH}) .{ }^{11} \mathrm{~B}$ NMR $\delta\left(\mathrm{CDCl}_{3}\right): 16.4$ (s, h.h.w. $=470 \mathrm{~Hz}$, BH). ${ }^{11} \mathrm{~B}\left\{{ }^{1} \mathrm{H}\right\}$ NMR $\delta\left(\mathrm{CDCl}_{3}\right): 16.4$ (s, h.h.w. $\left.=435 \mathrm{~Hz}, \mathrm{BH}\right) .{ }^{31} \mathrm{P}\left\{{ }^{1} \mathrm{H}\right\} \mathrm{NMR} \delta\left(\mathrm{CDCl}_{3}\right): 12.9(\mathrm{br}$. s, ${ }^{1} \mathrm{JPtP}_{\mathrm{PP}}=1497 \mathrm{~Hz}$, h.h.w. $\left.=175 \mathrm{~Hz}, \mathrm{PPh}_{2}\left({ }^{\mathrm{Me}} \mathrm{In}\right)\right) .{ }^{13} \mathrm{C}\left\{{ }^{1} \mathrm{H}\right\} \mathrm{NMR} \delta\left(\mathrm{CDCl}_{3}\right): 10.4\left(\mathrm{~d},{ }^{3} \mathrm{~J}_{\mathrm{CP}}=1.5 \mathrm{~Hz}\right.$ $\left.\mathrm{CH}_{3}\right), 115.2\left(\mathrm{~s},{ }^{\mathrm{mp} 5} \mathrm{C}\right), 119.1\left(\mathrm{~s},{ }^{\mathrm{In}} \mathrm{C}\right), 123.1\left(\mathrm{~s},{ }^{\mathrm{In}} \mathrm{C}\right), 124.7\left(\mathrm{~d},{ }^{1} \mathrm{~J}_{\mathrm{CP}}=44.9 \mathrm{~Hz},{ }^{\mathrm{In} 2} \mathrm{C}\right), 120.0\left(\mathrm{~d},{ }^{2} \mathrm{~J}_{\mathrm{CP}}\right.$ 
$\left.=3.9 \mathrm{~Hz},{ }^{\mathrm{In} 3} \mathrm{C}\right), 129.8\left(\mathrm{~d},{ }^{3} \mathrm{~J}_{\mathrm{CP}}=6.1 \mathrm{~Hz},{ }^{\mathrm{In} 3 \mathrm{a}} \mathrm{C}\right), 137.1\left(\mathrm{~d},{ }^{3} \mathrm{~J}_{\mathrm{CP}}=9.1 \mathrm{~Hz},{ }^{\mathrm{In} 7 \mathrm{a}} \mathrm{C}\right), 130.0\left(\mathrm{~s},{ }^{\mathrm{mp} 3} \mathrm{C}\right), 128.3$ $\left(\mathrm{d}, \mathrm{J}_{\mathrm{PC}}=9.5 \mathrm{~Hz},{ }^{\mathrm{Ph}} \mathrm{C}\right), 129.5\left(\mathrm{~d}, \mathrm{~J}_{\mathrm{PC}}=1.7 \mathrm{~Hz},{ }^{\mathrm{Ph}} \mathrm{C}\right), 132.9\left(\mathrm{~d}, \mathrm{~J}_{\mathrm{PC}}=13.8 \mathrm{~Hz},{ }^{\mathrm{Ph}} \mathrm{C}\right), 132.6\left(\mathrm{~d},{ }^{1} \mathrm{~J}_{\mathrm{CP}}=\right.$ 11.0 Hz, $\left.{ }^{\mathrm{i}-\mathrm{Ph}} \mathrm{C}\right), 136.0\left(\mathrm{~s},{ }^{\mathrm{mp} 4} \mathrm{C}\right), 142.3\left(\mathrm{~s},{ }^{\mathrm{mp} 6} \mathrm{C}\right), 178.1\left(\mathrm{~d},{ }^{3} \mathrm{~J}_{\mathrm{CP}}=20.8 \mathrm{~Hz},{ }^{\mathrm{mp} 2} \mathrm{C}\right), \mathrm{IR}\left(\mathrm{cm}^{-1}, \mathrm{ATR}\right.$ powder film) 2318w (B-H). MS (ESI) ${ }^{+}$m/z missing $731.1[\mathrm{M}-\mathrm{B}]^{+}, 316.1\left[\mathrm{HPPh}\left({ }^{\mathrm{Me}} \mathrm{In}\right)\right]^{+}$. Anal. [Found (calc)] for $\mathrm{C}_{31} \mathrm{H}_{27} \mathrm{BN}_{3} \mathrm{PPdS}_{2}$ : C 50.04\% (50.14\%), H 3.62\% (3.67\%), N 5.58\% (5.66\%).

Attempts to isolate and characterise $\left[\mathrm{PtH}\left\{\kappa^{3}-S, B, S-\mathrm{HB}(\mathrm{mp})_{2}\right\}\left(\mathrm{COE}^{\mathrm{OMe}}\right)\right]\left(\mathrm{Ptint}_{\mathrm{int}}\right)$. A Schlenk flask was charged with $\left[\mathrm{PtCl}\left(\mathrm{COE}^{\mathrm{OMe}}\right)\right]_{2}\left(25 \mathrm{mg}, 3.38 \times 10^{-5} \mathrm{~mol}\right)$ which was subsequently fully dissolved in $7.5 \mathrm{~mL}$ of DCM. $\mathrm{PMe}_{3} 1 \mathrm{M}$ in THF $\left(67.5 \mu \mathrm{L}, 6.75 \times 10^{-5} \mathrm{~mol}\right)$ was added to the solution followed by $\mathrm{Na}[\mathbf{B m p}]\left(17.3 \mathrm{mg}, 6.75 \times 10^{-5} \mathrm{~mol}\right)$. The reaction mixture was continuously stirred and allowed to react for $2.5 \mathrm{~h}$. The mixture was then filtered and reduced to $1 / 4$ its original volume under reduced pressure. Hexane $(15 \mathrm{~mL})$ was added to the stirring solution to precipitate a small amount of pale yellow solid. The solid product was separated from the remaining solution via cannula filtration before being washed with pentane $(4 \mathrm{~mL})$ and dried under vacuum. The compound started to decompose when it was placed back into solvent. Selected characterisation: ${ }^{1} \mathrm{H}$ NMR $\delta\left(\mathrm{CDCl}_{3}\right): 1.25-2.57\left(\mathrm{~m},{ }^{\mathrm{coe}} \mathrm{CH}_{2}\right), 3.07\left(\mathrm{~m},{ }^{\mathrm{coe}} \mathrm{CH}\right), 3.26\left(\mathrm{~s},{ }^{\mathrm{OMe}} \mathrm{CH}_{3}\right), 3.68\left(\mathrm{~m},{ }^{\mathrm{coe}} \mathrm{CH}\right)$, $5.60\left(\mathrm{~m},{ }^{\mathrm{coe}} \mathrm{CH}\right), 5.86\left(\mathrm{~m},{ }^{\mathrm{coe}} \mathrm{CH}\right), 6.74\left(\mathrm{~s}, 2 \mathrm{H},{ }^{\mathrm{mp}} \mathrm{CH}\right), 7.21\left(\mathrm{t}, 2 \mathrm{H},{ }^{\mathrm{mp}} \mathrm{CH}\right), 7.48\left(\mathrm{~m},{ }^{\mathrm{mp}} \mathrm{CH}\right), 7.55(\mathrm{~m}$, $\left.{ }^{\mathrm{mp}} \mathrm{CH}\right), 8.02\left(\mathrm{~s},{ }^{\mathrm{mp}} \mathrm{CH}\right), 8.26\left(\mathrm{~s},{ }^{\mathrm{mp}} \mathrm{CH}\right) .{ }^{1} \mathrm{H} \mathrm{NMR} \delta\left(\mathrm{CD}_{2} \mathrm{Cl}_{2}\right):-13.31\left(\mathrm{~s},{ }^{1} \mathrm{~J}_{\mathrm{PtH}}=1400 \mathrm{~Hz}, \mathrm{PtH}\right) .{ }^{11} \mathrm{~B}$ $\operatorname{NMR} \delta\left(\mathrm{CDCl}_{3}\right): 7.9$ (bs, h.h.w. $\left.=420 \mathrm{~Hz}, \mathrm{BH}\right) .{ }^{11} \mathrm{~B}\left\{{ }^{1} \mathrm{H}\right\} \mathrm{NMR} \delta\left(\mathrm{CDCl}_{3}\right): 7.9\left(\mathrm{bs},{ }^{1} \mathrm{~J}_{\mathrm{PtB}}=500 \mathrm{~Hz}\right.$, $\mathrm{BH})$.

Synthesis of $\left[\mathrm{Pd}\left\{\boldsymbol{\kappa}^{3}-S, B, S-\mathrm{HB}(\mathrm{mp})_{2}\right\}\left(\mathrm{PPh}_{3}\right)\right]$ (7) from Pd(COD)MeCl. A Schlenk flask was charged with $[\mathrm{Pd}(\mathrm{Me}) \mathrm{Cl}(\mathrm{COD})]\left(25 \mathrm{mg}, 9.43 \times 10^{-5} \mathrm{~mol}\right)$ which was fully dissolved in $5 \mathrm{~mL}$ of DCM. $\mathrm{PPh}_{3}\left(24.7 \mathrm{mg}, 9.43 \times 10^{-5} \mathrm{~mol}\right)$ was added to the solution followed by $\mathrm{Na}[\mathbf{B m p}](24.2 \mathrm{mg}$, $\left.9.43 \times 10^{-5} \mathrm{~mol}\right)$. The reaction mixture was continuously stirred and allowed to react for $1 \mathrm{~h}$. The 
mixture was then filtered and the volume was reduced to $<1 \mathrm{~mL}$ under reduced pressure. Hexane $(15 \mathrm{~mL})$ was added to the stirring solution to precipitate an orange solid. The solid product was separated from the remaining solution via cannula filtration before being washed with additional hexane $(5 \mathrm{~mL})$ and dried under dynamic. Yield: $171.2 \mathrm{mg}, 2.78 \times 10^{-4} \mathrm{~mol}, 78 \%$. The characterisation for this complex was the same as previously reported for this complex starting from $\left[\mathrm{PdCl}\left(\mathrm{COE}^{\mathrm{OMe}}\right)\right] 2 .{ }^{25 \mathrm{a}}$

Synthesis of $\left[\mathrm{Pd}\left\{\mathrm{\kappa}^{3}-\mathrm{S}, \boldsymbol{B}, S-\mathrm{HB}(\mathrm{mp})_{2}\right\}\left(\mathrm{PC} \mathbf{y}_{3}\right)\right]$ (8). A Schlenk flask was charged with $\left[\mathrm{PdCl}\left(\mathrm{COE}^{\mathrm{OMe})}\right]_{2}\left(100 \mathrm{mg}, 1.78 \times 10^{-4} \mathrm{~mol}\right)\right.$ which was fully dissolved in $30 \mathrm{~mL}$ of DCM. $\mathrm{PCy}$ $\left(100.1 \mathrm{mg}, 3.57 \times 10^{-4} \mathrm{~mol}\right)$ was added to the solution followed by $\mathrm{Na}[\mathbf{B m p}]\left(91.2 \mathrm{mg}, 3.54 \times 10^{-}\right.$ $\left.{ }^{4} \mathrm{~mol}\right)$. The reaction mixture was continuously stirred and allowed to react for $1 \mathrm{~h}$. The mixture was then filtered and the volume was reduced to $<1 \mathrm{~mL}$ under reduced pressure. Hexane (20 mL) was added to the stirring solution to precipitate a small amount of deep orange/ red solid. More solid was precipitated from the solution by reducing the volume of the hexane to approximately 1 $\mathrm{mL}$. The solid product was separated from the remaining solution via cannula filtration before being washed with pentane $(5 \mathrm{~mL})$ and dried under dynamic vacuum. Yield: $103.9 \mathrm{mg}, 1.68 \times 10^{-}$ ${ }^{4} \mathrm{~mol}, 47 \% .{ }^{1} \mathrm{H}$ NMR $\delta\left(\mathrm{CDCl}_{3}\right): 1.27\left(\mathrm{bm}, 3 \mathrm{H},{ }^{\mathrm{Cy} 4} \mathrm{CH}_{2}\right), 1.27\left(\mathrm{bm}, 6 \mathrm{H},{ }^{\mathrm{Cy}} \mathrm{CH}_{2}\right), 1.49(\mathrm{bm}, 6 \mathrm{H}$, $\left.{ }^{\mathrm{Cy} 2} \mathrm{CH}_{2}\right), 1.68\left(\mathrm{bs}, 3 \mathrm{H},{ }^{\mathrm{Cy} 4} \mathrm{CH}_{2}\right), 1.79\left(\mathrm{bd}, 6 \mathrm{H},{ }^{\mathrm{Cy} 3} \mathrm{CH}_{2}\right), 1.86\left(\mathrm{~m}, 3 \mathrm{H},{ }^{\mathrm{Cy} 1} \mathrm{CH}\right), 1.98\left(\mathrm{bd}, 6 \mathrm{H},{ }^{\mathrm{Cy} 2} \mathrm{CH}_{2}\right)$, $6.71\left(\tau \mathrm{d},{ }^{3} \mathrm{~J}_{\mathrm{HH}}=6.6 \mathrm{~Hz}, 2 \mathrm{H},{ }^{\mathrm{mp} 5} \mathrm{CH}\right), 7.29\left(\tau \mathrm{d},{ }^{3} \mathrm{~J}_{\mathrm{HH}}=7.5 \mathrm{~Hz}, 2 \mathrm{H},{ }^{\mathrm{mp} 4} \mathrm{CH}\right), 7.54\left(\mathrm{~d},{ }^{3} \mathrm{~J}_{\mathrm{HH}}=8.5 \mathrm{~Hz}\right.$, $\left.2 \mathrm{H},{ }^{\mathrm{mp} 3} \mathrm{CH}\right), 7.74\left(\mathrm{~d},{ }^{3} \mathrm{~J}_{\mathrm{HH}}=6.2 \mathrm{~Hz}, 2 \mathrm{H},{ }^{\mathrm{mp} 6} \mathrm{CH}\right) .{ }^{1} \mathrm{H}\left\{{ }^{11} \mathrm{~B}\right\} \mathrm{NMR} \delta\left(\mathrm{CDCl}_{3}\right): 5.67$ (bd, h.h.w. $=16.4$ $\mathrm{Hz}, \mathrm{BH}) .{ }^{11} \mathrm{~B}$ NMR $\delta\left(\mathrm{CDCl}_{3}\right): 14.7$ (s, h.h.w. $\left.=300 \mathrm{~Hz}, \mathrm{BH}\right) .{ }^{11} \mathrm{~B}\left\{{ }^{1} \mathrm{H}\right\} \mathrm{NMR} \delta\left(\mathrm{CDCl}_{3}\right): 14.6(\mathrm{~s}$, h.h.w. $=220 \mathrm{~Hz}, \mathrm{BH}) .{ }^{31} \mathrm{P}\left\{{ }^{1} \mathrm{H}\right\} \mathrm{NMR} \delta\left(\mathrm{CDCl}_{3}\right): 21.0$ (br s, h.h.w. $\left.=190 \mathrm{~Hz}, \mathrm{PCy}\right) .{ }^{13} \mathrm{C}\left\{{ }^{1} \mathrm{H}\right\}$ $\operatorname{NMR} \delta\left(\mathrm{CDCl}_{3}\right): 26.7\left(\mathrm{~s},{ }^{\mathrm{Cy} 4} \mathrm{C}\right), 27.9\left(\mathrm{~d},{ }^{3} \mathrm{~J}_{\mathrm{CP}}=9.8 \mathrm{~Hz},{ }^{\mathrm{Cy} 3} \mathrm{C}\right), 30.6\left(\mathrm{~d},{ }^{2} \mathrm{~J}_{\mathrm{CP}}=4.4 \mathrm{~Hz},{ }^{\mathrm{Cy} 2} \mathrm{C}\right), 33.7$ $\left(\mathrm{d},{ }^{1} \mathrm{~J}_{\mathrm{CP}}=5.4 \mathrm{~Hz},{ }^{\mathrm{Cy} 1} \mathrm{C}\right), 114.2\left(\mathrm{~s},{ }^{\mathrm{mp} 5} \mathrm{C}\right), 130.6\left(\mathrm{~s},{ }^{\mathrm{mp} 3} \mathrm{C}\right), 135.6\left(\mathrm{~s},{ }^{\mathrm{mp} 4} \mathrm{C}\right), 141.3\left(\mathrm{~d},{ }^{4} \mathrm{~J}_{\mathrm{CP}}=2.2 \mathrm{~Hz}\right.$, 
$\left.{ }^{\mathrm{mp} 6} \mathrm{C}\right), 179.1$ (d, $\left.{ }^{\mathrm{mp}} \mathrm{C}\right) . \mathrm{IR}\left(\mathrm{cm}^{-1}\right.$, ATR powder film) 2919, 2344 (B-H), $1598 \mathrm{~s}, 1540 \mathrm{~s}$ (pyridine). MS (ESI) ${ }^{+}: m / z 607.16$ [M - B]. Anal. [Found (calc)] for $\mathrm{C}_{28} \mathrm{H}_{42} \mathrm{BN}_{2} \mathrm{PPdS}_{2} \cdot 1 / 4 \mathrm{CH}_{2} \mathrm{Cl}_{2}$ : C $52.83 \%$ (53.00\%), H 6.76\% (6.69\%), N 4.63\% (4.38\%).

Synthesis of $\left[\operatorname{Pd}\left\{\boldsymbol{K}^{3}-S, B, S-H B(m p)_{2}\right\}\left(\mathbf{P C y p}_{3}\right)\right]$ (9). A Schlenk flask was charged with $\left[\mathrm{PdCl}\left(\mathrm{COE}^{\mathrm{OMe}}\right)\right]_{2}\left(100 \mathrm{mg}, 1.78 \times 10^{-4} \mathrm{~mol}\right)$ which was fully dissolved in $30 \mathrm{~mL}$ of DCM. $\mathrm{P}(\mathrm{c}-$ $\left.\mathrm{C}_{5} \mathrm{H}_{9}\right)_{3}\left(1.7 \mathrm{~mL}\right.$ of $0.21 \mathrm{M}$ in toluene, $\left.3.57 \times 10^{-4} \mathrm{~mol}\right)$ was added to the solution followed by $\mathrm{Na}[\mathbf{B m p}]\left(91.2 \mathrm{mg}, 3.54 \times 10^{-4} \mathrm{~mol}\right)$. The reaction mixture was continuously stirred and allowed to react for $1 \mathrm{~h}$. The mixture was then filtered and the volume was reduced to $<1 \mathrm{~mL}$ under reduced pressure. Hexane $(30 \mathrm{~mL})$ was added to the stirring solution to precipitate an orange/ red solid. The solid product was separated from the remaining solution via cannula filtration before being washed with pentane $(5 \mathrm{~mL})$ and dried under dynamic vacuum. Yield: $114.5 \mathrm{mg}, 1.99 \times 10^{-4} \mathrm{~mol}$, $56 \% .{ }^{1} \mathrm{H}$ NMR $\delta\left(\mathrm{CDCl}_{3}\right): 1.53\left(\mathrm{~m}, 6 \mathrm{H},{ }^{\mathrm{Cyp} 3} \mathrm{CH}_{2}\right), 1.74\left(\mathrm{~m}, 6 \mathrm{H},{ }^{\mathrm{Cyp} 3} \mathrm{CH}_{2}\right), 1,74\left(\mathrm{~m}, 6 \mathrm{H},{ }^{\mathrm{Cyp} 3} \mathrm{CH}_{2}\right)$, $1.92\left(\mathrm{~m}, 6 \mathrm{H},{ }^{\text {Cyp2 }} \mathrm{CH}_{2}\right), 2.09\left(\mathrm{~m}, 3 \mathrm{H},{ }^{\text {Cyp } 1} \mathrm{CH}\right), 6.71\left(\tau \mathrm{d},{ }^{3} \mathrm{~J}_{\mathrm{HH}}=6.6 \mathrm{~Hz}, 2 \mathrm{H},{ }^{\mathrm{mp} 5} \mathrm{CH}\right), 7.29\left(\tau \mathrm{d},{ }^{3} \mathrm{~J}_{\mathrm{HH}}\right.$ $\left.=7.6 \mathrm{~Hz}, 2 \mathrm{H},{ }^{\mathrm{mp} 4} \mathrm{CH}\right), 7.52\left(\mathrm{~d},{ }^{3} \mathrm{~J}_{\mathrm{HH}}=8.5 \mathrm{~Hz}, 2 \mathrm{H},{ }^{\mathrm{mp} 3} \mathrm{CH}\right), 7.73\left(\mathrm{~d},{ }^{3} \mathrm{~J}_{\mathrm{HH}}=6.3 \mathrm{~Hz}, 2 \mathrm{H},{ }^{\mathrm{mp} 6} \mathrm{CH}\right)$. ${ }^{1} \mathrm{H}\left\{{ }^{11} \mathrm{~B}\right\}$ NMR $\delta\left(\mathrm{CDCl}_{3}\right): 5.63\left(\mathrm{~d},{ }^{3} \mathrm{JPH}_{\mathrm{PH}}=5.9 \mathrm{~Hz}\right.$, h.h.w. $\left.=14.7 \mathrm{~Hz}, \mathrm{BH}\right) .{ }^{11} \mathrm{~B}$ NMR $\delta\left(\mathrm{CDCl}_{3}\right):$ 14.7 (s, h.h.w. $=281 \mathrm{~Hz}, \mathrm{BH}) .{ }^{11} \mathrm{~B}\left\{{ }^{1} \mathrm{H}\right\} \operatorname{NMR} \delta\left(\mathrm{CDCl}_{3}\right): 14.7$ (s, h.h.w. $\left.=200 \mathrm{~Hz}, \mathrm{BH}\right) .{ }^{31} \mathrm{P}\left\{{ }^{1} \mathrm{H}\right\}$ NMR $\delta\left(\mathrm{CDCl}_{3}\right): 20.3$ (br. d, h.h.w. $\left.=200 \mathrm{~Hz}, \mathrm{PCyp} 3\right) \cdot{ }^{13} \mathrm{C}\left\{{ }^{1} \mathrm{H}\right\} \mathrm{NMR} \delta\left(\mathrm{CDCl}_{3}\right): 26.3\left(\mathrm{~d},{ }^{3} \mathrm{~J}_{\mathrm{CP}}=\right.$ $\left.8.0 \mathrm{~Hz},{ }^{\text {Cyp } 3} \mathrm{C}\right), 30.6\left(\mathrm{~d},{ }^{2} \mathrm{~J}_{\mathrm{CP}}=7.4 \mathrm{~Hz},{ }^{\mathrm{Cyp} 2} \mathrm{C}\right), 36.3\left(\mathrm{~d},{ }^{1} \mathrm{~J}_{\mathrm{CP}}=8.5 \mathrm{~Hz},{ }^{\mathrm{Cyp} 1} \mathrm{C}\right), 114.2\left(\mathrm{~s},{ }^{\mathrm{mp} 5} \mathrm{C}\right), 130.5$ $\left(\mathrm{s},{ }^{\mathrm{mp} 3} \mathrm{C}\right), 135.6\left(\mathrm{~s},{ }^{\mathrm{mp} 4} \mathrm{C}\right), 141.3\left(\mathrm{~d},{ }^{4} \mathrm{~J}_{\mathrm{CP}}=2.4 \mathrm{~Hz},{ }^{\mathrm{mp} 6} \mathrm{C}\right), 179.1\left(\mathrm{~d},{ }^{3} \mathrm{~J}_{\mathrm{CP}}=19.9 \mathrm{~Hz},{ }^{\mathrm{mp}} \mathrm{C}\right) . \mathrm{IR}\left(\mathrm{cm}^{-1}\right.$, ATR powder film) $2331(\mathrm{~B}-\mathrm{H})$. MS $(\mathrm{ESI})^{+}: \mathrm{m} / \mathrm{z} 565.11$ [M - B]. Anal. [Found (calc)] for $\mathrm{C}_{25} \mathrm{H}_{36} \mathrm{BN}_{2} \mathrm{PPdS}_{2}$ : C 52.12\% (52.05\%), H 6.46\% (6.29\%), N 5.00\% (4.86\%).

Synthesis of $\left[\mathbf{P d}\left\{\boldsymbol{K}^{3}-\mathrm{S}, \boldsymbol{B}, \boldsymbol{S}-\mathbf{H B}(\mathrm{mp})_{2}\right\}\left(\mathbf{P h}{ }_{2} \mathbf{P}(\mathbf{0}-\mathrm{tol})\right)\right]$ (10). A Schlenk flask was charged with $\left[\mathrm{PdCl}\left(\mathrm{COE}^{\mathrm{OMe}}\right)\right]_{2}\left(100 \mathrm{mg}, 1.78 \times 10^{-4} \mathrm{~mol}\right)$ which was fully dissolved in $30 \mathrm{~mL}$ of DCM. $\mathrm{PPh}_{2}(\mathrm{O}-$ 
tol) $\left(99 \mathrm{mg}, 3.57 \times 10^{-4} \mathrm{~mol}\right)$ was added to the solution followed by $\mathrm{Na}[\mathbf{B m p}]\left(91.2 \mathrm{mg}, 3.54 \times 10^{-}\right.$

${ }^{4} \mathrm{~mol}$ ). The reaction mixture was continuously stirred and allowed to react for $1 \mathrm{~h}$. The mixture was then filtered and the volume was reduced to $<1 \mathrm{~mL}$ under reduced pressure. Hexane (20 mL) was added to the stirring solution to precipitate an orange solid. The solid product was separated from the remaining solution via cannula filtration before being washed with additional hexane (5 $\mathrm{mL})$ and dried under dynamic. Yield: $171.2 \mathrm{mg}, 2.78 \times 10^{-4} \mathrm{~mol}, 78 \% .{ }^{1} \mathrm{H} \mathrm{NMR} \delta\left(\mathrm{CDCl}_{3}\right)^{48}: 2.56$

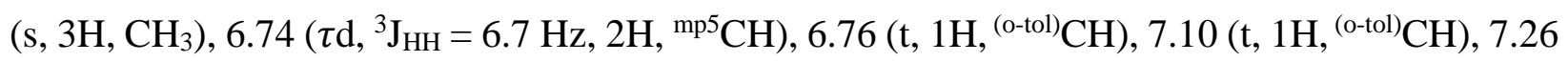
(unresolved, $1 \mathrm{H},{ }^{(0-\text { tol) }} \mathrm{CH}$ ), $7.30\left(\tau \mathrm{d},{ }^{3} \mathrm{~J}_{\mathrm{HH}}=7.4 \mathrm{~Hz}, 2 \mathrm{H},{ }^{\mathrm{mp} 4} \mathrm{CH}\right), 7.33$ (unresolved, $1 \mathrm{H},{ }^{(\text {o-tol) }} \mathrm{CH}$ ), $7.37\left(\mathrm{~m}, 2 \mathrm{H},{ }^{\mathrm{Ph}} \mathrm{CH}\right), 7.37\left(\mathrm{~m}, 4 \mathrm{H},{ }^{\mathrm{Ph}} \mathrm{CH}\right), 7.60\left(\mathrm{~m}, 4 \mathrm{H},{ }^{\mathrm{Ph}} \mathrm{CH}\right), 7.50\left(\mathrm{~d},{ }^{3} \mathrm{~J} \mathrm{HH}=8.5 \mathrm{~Hz}, 2 \mathrm{H},{ }^{\mathrm{mp}} \mathrm{CH}\right)$, $7.74\left(\mathrm{~d},{ }^{3} \mathrm{~J}_{\mathrm{HH}}=6.2 \mathrm{~Hz}, 2 \mathrm{H},{ }^{\mathrm{mp} 6} \mathrm{CH}\right) .{ }^{1} \mathrm{H}\left\{{ }^{11} \mathrm{~B}\right\} \mathrm{NMR} \delta\left(\mathrm{CDCl}_{3}\right): 5.81(\mathrm{~s}, \mathrm{BH}) .{ }^{11} \mathrm{~B} \mathrm{NMR} \delta\left(\mathrm{CDCl}_{3}\right):$ 13.5 (s, h.h.w. $=300 \mathrm{~Hz}, \mathrm{BH}) .{ }^{11} \mathrm{~B}\left\{{ }^{1} \mathrm{H}\right\} \mathrm{NMR} \delta\left(\mathrm{CDCl}_{3}\right): 13.6$ (s, h.h.w. $\left.=240 \mathrm{~Hz}, \mathrm{BH}\right) \cdot{ }^{31} \mathrm{P}\left\{{ }^{1} \mathrm{H}\right\}$ $\operatorname{NMR} \delta\left(\mathrm{CDCl}_{3}\right): 5.6$ (br. s, h.h.w. $\left.=185 \mathrm{~Hz}, \mathrm{Ph}_{2} \mathrm{P}(\mathrm{o}-\mathrm{tol})\right) \cdot{ }^{13} \mathrm{C}\left\{{ }^{1} \mathrm{H}\right\} \mathrm{NMR} \delta\left(\mathrm{CDCl}_{3}\right): 23.2\left(\mathrm{~d}, \mathrm{CH}_{3}\right)$, $114.4\left(\mathrm{~s},{ }^{\mathrm{mp} 5} \mathrm{C}\right), 125.6\left(\mathrm{~d},{ }^{(0-\mathrm{tol}) 4} \mathrm{C}\right), 128.5\left(\mathrm{~d}, \mathrm{JPC}=8.8 \mathrm{~Hz},{ }^{\mathrm{Ph}} \mathrm{C}\right), 129.3\left(\mathrm{~s},{ }^{\mathrm{Ph}} \mathrm{C}\right), 130.5\left(\mathrm{~s},{ }^{\mathrm{mp} 3} \mathrm{C}\right), 130.9$ $\left(\mathrm{d}, \mathrm{J}_{\mathrm{PC}}=6.2 \mathrm{~Hz},{ }^{(0-\mathrm{tol}) 3} \mathrm{C}\right), 132.5\left(\mathrm{~d}, \mathrm{~J}_{\mathrm{PC}}=4.4 \mathrm{~Hz},{ }^{(0-\text { tol }) 5} \mathrm{C}\right), 134.6\left(\mathrm{~d}, \mathrm{~J}_{\mathrm{PC}}=15.4 \mathrm{~Hz},{ }^{\mathrm{Ph}} \mathrm{C}\right), 135.7(\mathrm{~s}$, $\left.{ }^{\mathrm{mp} 4} \mathrm{C}\right), 141.1\left(\mathrm{~s},{ }^{\mathrm{mp} 6} \mathrm{C}\right), 179.1\left(\mathrm{~d},{ }^{3} \mathrm{~J}_{\mathrm{CP}}=16.1 \mathrm{~Hz},{ }^{\mathrm{mp} 2} \mathrm{C}\right) . \mathrm{IR}\left(\mathrm{cm}^{-1}\right.$, ATR powder film) $2347 \mathrm{w}(\mathrm{B}-\mathrm{H})$. ESI + MS: $m / z 603.0[\mathrm{M}-\mathrm{BH}]^{+}, 494.0[\mathrm{M}-\{\mathrm{HB}(\mathrm{mp})\}]^{+}$. Unfortunately, satisfactory elemental analysis could not be obtained for this compound.

\section{X-ray Crystallography}

Single-crystal X-ray diffraction studies of complexes $2,3,8,9$ and 10 were carried out at the UK National Crystallography Service at the University of Southampton. ${ }^{49}$ Single crystals of complexes 2, 3, 8 and 9 were obtained by allowing a saturated ether solution stand at room temperature. Single crystals of complex $\mathbf{1 0}$ were obtained from a concentrated toluene- $\mathrm{d}_{8}$ solution. A single crystal from each sample was mounted on a MITIGEN holder in perfluoroether oil on a 
Rigaku FRE+ equipped with HF Varimax confocal mirrors and an AFC12 goniometer and HG Saturn 724+ detector. The crystals were kept at $\mathrm{T}=100(2) \mathrm{K}$ during data collection. Data were collected and processed and empirical absorption corrections were carried out using CrysAlisPro ${ }^{50}$ The structures were solved by Intrinsic Phasing using the ShelXT structure solution program ${ }^{51}$ and refined on $F_{o}{ }^{2}$ by full-matrix least squares refinement with version 2014/7 of ShelXL ${ }^{52}$ as implemented in Olex $2,{ }^{53}$ The structures for complexes $\mathbf{2 , 3 , 9}$ and $\mathbf{1 0}$ contained various degrees of disorder. They also contained two independent complexes in the asymmetric unit. In complex $\mathbf{2}$, the structure contained disorder of the $\left[\mathrm{HB}(\mathrm{mp})_{2}\right]$ ligand occupying in a ratio of 51:49 in each complex. In complex $\mathbf{3}$, the structure contained disorder of two of the cyclopentene rings of one complex occupying in ratios of 44:55 and 84:16, respectively. In complex $\mathbf{9}$, the structure also contained disorder of two of the cyclopentene rings of one complex occupying in ratios of 53:47 and 79:21, respectively. In complex 10, the structure contained disorder of the $\left[\mathrm{HB}(\mathrm{mp})_{2}\right]$ ligand in one complex occupying in a ratio of 80:20. Complex 8 only contained one complex within the asymmetric unit with no disorder. All hydrogen atom positions were calculated geometrically and refined using the riding model. Crystal Data for $2 . \mathrm{C}_{28} \mathrm{H}_{42} \mathrm{BN}_{2} \mathrm{PPtS}_{2}, M_{r}=707.62$, monoclinic, $\mathrm{P} 21 / \mathrm{n}$ (No. 14), $\mathrm{a}=17.3342(3) \AA ⿻$, $\mathrm{b}=9.8075(2) \AA, \mathrm{c}=34.4228(5) \AA, \beta=94.7630(10)^{\circ}, \alpha=\gamma=$ $90^{\circ}, V=5831.84(18) \AA^{3}, T=100(2) \mathrm{K}, Z=8, Z^{\prime}=2, \mu\left(\mathrm{MoK}_{\alpha}\right)=5.030,54250$ reflections measured, 13345 unique $\left(R_{\text {int }}=0.0575\right)$ which were used in all calculations. The final $w R_{2}$ was 0.0795 (all data) and $R_{I}$ was 0.0442 (I > 2(I)). Crystal Data for 3. $\mathrm{C}_{25} \mathrm{H}_{36} \mathrm{BN}_{2} \mathrm{PS}_{2} \mathrm{Pt}, M_{r}=665.55$, triclinic, P-1 (No. 2), a = 9.49076(18) $\mathrm{A}, \mathrm{b}=16.1437(3) \AA, \mathrm{c}=17.6862(4) \AA, \alpha=75.2432(18)^{\circ}$, $\beta=75.3619(18)^{\circ}, \gamma=84.6537(16)^{\circ}, V=2534.17(9) \AA^{3}, T=100(2) \mathrm{K}, Z=4, Z^{\prime}=2, \mu\left(\mathrm{MoK}_{\alpha}\right)=$ 5.782, 33047 reflections measured, 11545 unique $\left(R_{\text {int }}=0.0187\right)$ which were used in all calculations. The final $w R_{2}$ was 0.0407 (all data) and $R_{1}$ was 0.0177 (I > 2(I)). Crystal Data for 8 . 
$\mathrm{C}_{28} \mathrm{H}_{42} \mathrm{BN}_{2} \mathrm{PS}_{2} \mathrm{Pd}, M_{r}=618.93$, monoclinic, $\mathrm{P} 2{ }_{1} / \mathrm{c}($ No. 14), $\mathrm{a}=14.9962(4) \AA, \mathrm{b}=9.5779(2) \AA$, $\mathrm{c}=20.0916(6) \AA, \beta=95.606(3)^{\circ}, \alpha=\gamma=90^{\circ}, V=2872.00(13) \AA^{3}, T=100(2) \mathrm{K}, Z=4, Z^{\prime}=1$, $\mu\left(\operatorname{MoK}_{\alpha}\right)=0.867,21729$ reflections measured, 6541 unique $\left(R_{\text {int }}=0.0620\right)$ which were used in all calculations. The final $w R_{2}$ was 0.0838 (all data) and $R_{1}$ was 0.0319 (I > 2(I)). Crystal Data for 9 . $\mathrm{C}_{25} \mathrm{H}_{36} \mathrm{BN}_{2} \mathrm{PS}{ }_{2} \mathrm{Pd}, M_{r}=576.86$, triclinic, $\mathrm{P}-1$ (No. 2), $\mathrm{a}=9.4416(3) \AA, \mathrm{b}=16.2327(4) \AA, \mathrm{c}=$ 17.7301(5) $\AA, \alpha=75.064(2)^{\circ}, \beta=75.481(2)^{\circ}, \gamma=84.696(2)^{\circ}, V=2540.60(13) \AA^{3}, T=100(2) \mathrm{K}$, $Z=4, Z^{\prime}=2, \mu\left(\operatorname{MoK}_{\alpha}\right)=0.975,33439$ reflections measured, 11550 unique $\left(R_{\text {int }}=0.0210\right)$ which were used in all calculations. The final $w R_{2}$ was 0.0555 (all data) and $R_{1}$ was 0.0233 (I > 2(I)). Crystal Data for 10. $\mathrm{C}_{29} \mathrm{H}_{26} \mathrm{BN}_{2} \mathrm{PPdS}_{2}$ 0.2( $\left.\mathrm{C}_{7} \mathrm{D}_{8}\right), M_{r}=634.85$, triclinic, P-1 (No. 2), a = $10.0339(4) \AA, \mathrm{b}=14.6916(5) \AA, \mathrm{c}=19.2246(8) \AA, \alpha=89.410(3)^{\circ}, \beta=75.465(3)^{\circ}, \gamma=86.799(3)^{\circ}$, $V=2738.96(19) \AA^{3}, T=100(2) \mathrm{K}, Z=4, Z^{\prime}=2, \mu\left(\mathrm{MoK}_{\alpha}\right)=0.912,32792$ reflections measured, 12331 unique $\left(R_{\text {int }}=0.0292\right)$ which were used in all calculations. The final $w R_{2}$ was 0.1105 (all data) and $R_{I}$ was $0.0478(\mathrm{I}>2(\mathrm{I})$ ). A summary of the crystallographic data collection parameters and refinement details for all complexes are presented in the supporting information. Anisotropic parameters, bond lengths and (torsion) angles for these structures are available from the CIF files which have been deposited with the Cambridge Crystallographic Data Centre and given the following deposition numbers, 1842135 (2), 1842137 (3), 1842138 (8), 1842139 (9) and 1842136 (10). These data can be obtained free of charge from The Cambridge Crystallographic Data Centre via www.ccdc.cam.ac.uk/data_request/cif. 


\section{REFERENCES}

1 Moulton, C. J.; Shaw, B. L. Transition Metal-Carbon Bonds. Part XLII. Complexes of Nickel, Palladium, Platinum, Rhodium and Iridium with the Tridentate Ligand 2,6-Bis[(dit-butylphosphino)methyl]phenyl. J. Chem. Soc., Dalton Trans. 1976, 1020-1024.

2 a) Werkmeister, S.; Neumann, J.; Junge, K.; Beller, M. Pincer-Type Complexes for Catalytic (De)Hydrogenation and Transfer (De)Hydrogenation Reactions: Recent Progress. Chem. Eur. J. 2015, 21, 12226-12250; b) Szabo, K. J.; Wendt O. F. (Eds), Pincer and Pincer-Type Complexes: Applications in Organic Synthesis and Catalysis 2014, John Wiley and Sons; c) Kumar, A.; Bhatti T. M.; Goldman, A. S. Dehydrogenation of Alkanes and Aliphatic Groups by Pincer-Ligated Metal Complexes. Chem. Rev. 2017, 117, 1235712384; d) Murugesan, S.; Kirchner, K. Non-precious metal complexes with an anionic PCP pincer architecture. Dalton Trans. 2016, 45, 416-439; e) Farrell, K.; Albrecht, M. Late Transition Metal Complexes with Pincer Ligands that Comprise N-Heterocyclic Carbene Donor Sites. In: G. van Koten and R. Gossage (eds) The Privileged Pincer-Metal Platform: Coordination Chemistry \& Applications. Topics in Organometallic Chemistry 2015, 54. Springer, Cham.

3 For recent examples see: a) Fu, S.; Shao, Z.; Wang, Y.; Liu, Q. Manganese-Catalyzed Upgrading of Ethanol into 1-Butanol. J. Am. Chem. Soc. 2017, 139, 11941-11948; b) Yuwen, J.; Chakraborty, S.; Brennessel W. W.; Jones, W. D. Additive-Free CobaltCatalyzed Hydrogenation of Esters to Alcohols. ACS Catal. 2017, 7, 3735-3740; c) Tondreau, A. M.; Michalczyk R.; Boncella, J. M. Reversible 1,2-Addition of Water To Form a Nucleophilic Mn(I) Hydroxide Complex: A Thermodynamic and Reactivity Study. Organometallics 2017, 36, 4179-4183; d) Lombardi, B. M. P.; Brown, R. M.; Gendy, C.; 
Chang, C. Y.; Chivers T.; Roesler, R. Nickel and Platinum PCP Pincer Complexes Incorporating an Acyclic Diaminoalkyl Central Moiety Connecting Imidazole or Pyrazole Rings. Organometallics 2017, 36, 3250-3256; e) Smith, S. A. M.; Lagaditis, P. O.; Lüpke, A.; Lough, A. J.; Morris, R. H. Unsymmetrical Iron P-NH-P' Catalysts for the Asymmetric Pressure Hydrogenation of Aryl Ketones. Chem. Eur. J. 2017, 23, 7212-7216; f) Nguyen, D. H.; Trivelli, X.; Capet, F.; Paul, J.-F.; Dumeignil F.; Gauvin, R. M. Manganese Pincer Complexes for the Base-Free, Acceptorless Dehydrogenative Coupling of Alcohols to Esters: Development, Scope, and Understanding. ACS Catalysis 2017, 7, 2022-2032; g) Papa, V.; Cabrero-Antonino, J. R.; Alberico, E.; Spanneberg, A.; Junge, K.; Jungea, H.; Beller, M. Efficient and selective hydrogenation of amides to alcohols and amines using a well-defined manganese-PNN pincer complex. Chem. Sci. 2017, 8, 3576-3585; h) Krishnakumar, V.; Chatterjee, B.; Gunanathan, C. Ruthenium-Catalyzed Urea Synthesis by N-H Activation of Amines. Inorg. Chem. 2017, 56, 7278-7284; i) Grätz, M.; Bäcker, A.; Vondung, L.; Maser, L.; Reinckea, A.; Langer, R. Donor ligands based on tricoordinate boron formed by B-H-activation of bis(phosphine)boronium salts. Chem. Commun. 2017. 53. 7230-7233; j) Salvarese, N.; Refosco, F.; Seraglia, R.; Roverso, M.; Dolmella, A.; Bolzati, C. Synthesis and characterization of rhenium(III) complexes with $\left(\mathrm{Ph}_{2} \mathrm{PCH}_{2} \mathrm{CH}_{2}\right)_{2} \mathrm{NR}$ diphosphinoamine ligands. Dalton Trans. 2017, 46, 9180-9191; k) Smith, N. E.; Bernskoetter, W. H.; Hazari, N.; Mercado, B. Q. Synthesis and Catalytic Activity of PNP-Supported Iron Complexes with Ancillary Isonitrile Ligands. Organometallics 2017, 36, 3995-4004; 1) Comanescu, C. C.; Iluc, V. M. E-H (E = N, O) Bond Activation by a Nucleophilic Palladium Carbene. Polyhedron 2018, 143, 176-183; m) Garbe, M.; Junge, K.; Walker, S.; Wei, Z.; Jiao, H.; Spannenberg, A.; Bachmann, S.; 
Scalone, M.; Beller, M. Manganese(I)-catalyzed Enantioselective Hydrogenation of Ketones using a Defined Chiral PNP Pincer Ligand. Angew. Chem., Int. Ed. 2017, 56, 11237-11241; n) LaPierre, E. A.; Clapson, M. L.; Piers, W. E.; Maron, L.; Spasyuk, D. M.; Gendy, C. Oxygen Atom Transfer to Cationic PCPNi(II) Complexes Using Amine-N-Oxides. Inorg. Chem. 2018, 57, 495-506; o) Nguyen, D. H.; Morin, Y.; Zhang, L.; Trivelli, X.; Capet, F.; Paul, S.; Desset, S.; Dumeignil, F.; Gauvin, R. M. Earthabundant transition metals-catalyzed oxidative transformations of bio-sourced alcohols ChemCatChem. 2017, 9, 2652-2660; p) Mills, M. R.; Barnes, C. L.; Bernskoetter, W. H. Influences of Bifunctional PNP-Pincer Ligands on Low Valent Cobalt Complexes Relevant to CO2 Hydrogenation. Inorg Chem. 2018, 57, 1590-1597.

4 a) Kumar, S.; Sharma, R. P.; Venugopalan, P.; Gondil, V. S.; Chhibber, S.; Aree, T.; Witwicki, M.; Ferretti, V. Hybrid inorganic-organic complexes: Synthesis, spectroscopic characterization, single crystal X-ray structure determination and antimicrobial activities of three copper(II)-diethylenetriamine-p-nitrobenzoate complexes. Inorg. Chimica Acta. 2018, 469, 288-297; b) Hatcher, L. E.; Raithby, P. R. The impact of hydrogen bonding on 100\% photo-switching in solid-state nitro-nitrito linkage isomers. CrystEngComm 2017, 19, 6297-6392; c) Yilmaz, V. T.; Icsel, C.; Suyunova, F.; Aygun, M.; Cevatemrec, B.; Ulukayad, E. Synthesis, structures, DNA/protein binding, molecular docking, anticancer activity and ROS generation of $\mathrm{Ni}(\mathrm{II}), \mathrm{Cu}(\mathrm{II})$ and $\mathrm{Zn}$ (II) 5,5-diethylbarbiturate complexes with bis(2-pyridylmethyl)amine and terpyridine. New J. Chem. 2017, 41, 8092-8106; d) Du, C.-C.; Fan, J.-Z.; Wan, X.-F.; Zhou, S.-B.; Wang, D.-Z. New metal-organic complexes based on bis(tetrazole) ligands: Synthesis, structures and properties. J. Mol. Struct. 2017, 1133, 348-357; e) Rühlig, K.; Abylaikhan, A.; Aliabadi, A.; Kataev, V.; Liebing, S.; 
Schwalbe, S.; Trepte, K.; Ludt, C.; Kortus, J.; Büchner, B.; Rüffer, T.; Langa, H. Ni ${ }^{\mathrm{II}}$ formate complexes with bi- and tridentate nitrogen-donor ligands: synthesis, characterization, and magnetic and thermal properties. Dalton Trans. 2017, 46, 39633979; f) Massoud, S. S.; Williams, G. F.; Louka, F. R.; Henary, M. M.; Herchel, R.; Trávníček, Z.; Fischerd, R. C.; Mautner, F. A. Croconato-bridged copper(II) complexes: synthesis, structure and magnetic characterization. New J. Chem. 2017, 41, 3846-3856; g) Areas, E. S.; da S. Bronsato, B. J.; Pereira, T. M.; Guedes, G. P.; da S. Miranda, F.; Kümmerle, A. E.; da Cruz, A. G. B.; Neves, A. P. Novel Co ${ }^{\mathrm{III}}$ complexes containing fluorescent coumarin-N-acylhydrazone hybrid ligands: Synthesis, crystal structures, solution studies and DFT calculations. Spectrochim. Acta. Part A. 2017, 187, 130-142; h) Jin, X.; Davies, R. P. Copper-catalysed aromatic-Finkelstein reactions with amine-based ligand systems. Catal. Sci. Technol. 2017, 7, 2110-2117; i) Ranasinghe, K.; Pakhomova, S.; Marzilli, P. A.; Marzilli, L. G. A Very Rare Example of a Structurally Characterized 3'GMP Metal Complex. NMR and Synthetic Assessment of Adducts Formed by Guanine Derivatives with $\left[\mathrm{Pt}\left(\mathrm{L}^{\text {tri }}\right) \mathrm{Cl}\right] \mathrm{Cl}$ Complexes with an $\mathrm{N}, \mathrm{N}^{\prime}, \mathrm{N}^{\prime \prime}$ Tridentate Ligand $\left(\mathrm{L}^{\text {tri }}\right)$ Terminated by Imidazole Rings. Inorg. Chem. 2017, 56, 8462-8477; j) Huang, X.; Li, J.; Shen, G.; Xin, N.; Lin, Z.; Chi, Y.; Dou, J.; Lia, D.; Hu, C. Three Pd-decavanadates with a controllable molar ratio of Pd to decavanadate and their heterogeneous aerobic oxidation of benzylic C-H bonds. Dalton Trans. 2018, 47, 726-733.

5 a) Hallinger, M. R.; Gerhard, A. C.; Ritz, M. D.; Sacks, J. S.; Poutsma, J. C.; Pike, R. D.; Wojtas, L.; Bebout, D. C. Metal Substitution and Solvomorphism in Alkylthiolate-Bridged $\mathrm{Zn}_{3}$ and $\mathrm{HgZn} 2$ Metal Clusters. ACS Omega 2017, 2, 6391-6404; b) Puylaert, P.; van Heck, R.; Fan, Y.; Spannenberg, A.; Baumann, W.; Beller, M.; Medlock, J.; Bonrath, W.; Lefort, 
L.; Hinze, S.; de Vries, J. G. Selective Hydrogenation of $\alpha, \beta$-Unsaturated Aldehydes and Ketones by Air-Stable Ruthenium NNS Complexes. Chem. Eur. J. 2017, 23, 8473 - 8481;

c) Takeda, N.; Tanaka, Y.; Oma, R.; Sakakibara, F.; Unno, M. Activation of C-S Bond by Group 10 Metal Complexes: Reaction of Phosphine Ligand Tethered with Three tertButylthiophenyl Groups with Group 10 Metal Compounds. Bull. Chem. Soc. Jpn. 2016, 89, 922-930; d) Ostovana, A.; Ghaedib, M.; Arabib, M.; Asfaramba, A. Hollow porous molecularly imprinted polymer for highly selectiveclean-up followed by influential preconcentration of ultra-traceglibenclamide from bio-fluid. J. Chromatogr. A 2017, 1520, $65-74$.

6 a) Hossain, M. K.; Haukka, M.; Sillanpaa, R.; Hrovat, D. A.; Richmond, M. G.; Nordlander, E.; Lehtonen, A. Syntheses and catalytic oxotransfer activities of oxo molybdenum(VI) complexes of a new aminoalcohol phenolate ligand. Dalton Trans. 2017, 46, 7051-7060; b) Arıcı, M.; Yeşilel, O. Z.; Acar, E.; Dege, N. Synthesis, characterization and properties of nicotinamide and isonicotinamide complexes with diverse dicarboxylic acids. Polyhedron 2017, 127, 293-301.

7 a) Houghton, J.; Dyson, G.; Douthwaite, R. E.; Whitwooda, A. C.; Kariukib, B. M. Structural variation, dynamics, and catalytic application of palladium(II) complexes of diN-heterocyclic carbene-amine ligands. Dalton Trans. 2007, 3065-3073; b) Douthwaite, R. E.; Houghtona, J.; Kariukib, B. M. The synthesis of a di-N-heterocyclic carbene-amido complex of palladium(II). Chem.Commun. 2004, 698-699; c) Petz, W.; Neumüller, B. New platinum complexes with carbodiphosphorane as pincer ligand via ortho phenyl metalation. Polyhedron 2011, 30, 1779-1784. 
a) DeMott, J. C.; Gu, W.; McCulloch, B. J.; Herbert, D. E.; Goshert, M. D.; Walensky, J. R.; Zhou, J.; Ozerov, O. V. Silyl-Silylene Interplay in Cationic PSiP Pincer Complexes of Platinum. Organometallics 2015, 34, 3930-3933; b) Imayoshi, R.; Nakajima, K.; Takaya, J.; Iwasawa, N.; Nishibayashi, Y. Synthesis and Reactivity of Iron- and Cobalt-Dinitrogen Complexes Bearing PSiP-Type Pincer Ligands toward Nitrogen Fixation. Eur. J. Inorg. Chem. 2017, 3769-3778; c) Zhu, C.; Takaya, J.; Iwasawa, N. Use of Formate Salts as a Hydride and $\mathrm{CO}_{2}$ Source in PGeP-Palladium Complex-Catalyzed Hydrocarboxylation of Allenes. Org. Lett. 2015, 17, 1814-1817; d) Kameo, H.; Ikeda, K.; Sakaki, S.; Takemoto, S.; Nakazawac, H.; Matsuzakaa, H. Experimental and theoretical studies of $\mathrm{Si}-\mathrm{Cl}$ and $\mathrm{Ge}-$ $\mathrm{Cl} \sigma$-bond activation reactions by iridium-hydride. Dalton Trans. 2016, 45, 7570- 7580; e) Takaya, J.; Nakamura, S.; Iwasawa, N. Synthesis, Structure, and Catalytic Activity of Palladium Complexes Bearing a Tridentate PXP-Pincer Ligand of Heavier Group 14 Element (X = Ge, Sn). Chem. Lett. 2012, 41, 967-969.

9 Yamashita, M. The Organometallic Chemistry of Boron-Containing Pincer Ligands based on Diazaboroles and Carboranes. Bull. Chem. Soc. Jpn. 2016, 89, 269-281.

10 Shih, W.-C.; Gu, W.; MacInnis, M. C.; Herbert, D. E.; Ozerov, O. V. Boryl/Borane Interconversion and Diversity of Binding Modes of Oxygenous Ligands in PBP Pincer Complexes of Rhodium. Organometallics 2017, 36, 1718-1726.

11 a) Eleazer, B. J.; Smith, M. D.; Peryshkov, D. V. POBOP pincer complexes of nickel(II): Synthesis and $\mathrm{BH}$ activation of the carborane ligand upon oxidation with iodine. $J$. Organomet. Chem. 2017, 829, 42-47; b) Eleazer, B. J.; Smith, M. D.; Popov, A. A.; Peryshkov, D. V. (BB)-Carboryne Complex of Ruthenium: Synthesis by Double B-H 
Activation at a Single Metal Center. J. Am. Chem. Soc. 2016, 138, 10531-10538; c) Eleazer, B. J.; Smith, M. D.; Peryshkov, D. V. Metal- and Ligand-Centered Reactivity of meta-Carboranyl-Backbone Pincer Complexes of Rhodium. Organometallics 2016, 35, 106-112. d) Eleazer, B. J.; Smith, M. D.; Popov, A. A.; Peryshkov, D. V. Rapid reversible borane to boryl hydride exchange by metal shuttling on the carborane cluster surface. Chem. Sci. 2017, 8, 5399-5407.

12 Neshat, A.; Shahsavari, H. R.; Mastrorilli, P.; Todisco, S.; Haghighi M. G.; Notash, B. A Borane Platinum Complex Undergoing Reversible Hydride Migration in Solution. Inorg. Chem. 2018, 57, 1398-1407.

13 Lin, T.-P.; Peters, J. C. Boryl-Mediated Reversible $\mathrm{H}_{2}$ Activation at Cobalt: Catalytic Hydrogenation, Dehydrogenation, and Transfer Hydrogenation. J. Am. Chem. Soc. 2013, $135,15310-15313$.

14 Zech, A.; Haddow, M. F.; Othman, H.; Owen, G. R. Utilizing the 8-Methoxycyclooct-4en-1-ide Unit As a Hydrogen Atom Acceptor en Route to "Metal-Borane Pincers". Organometallics 2012, 31, 6753-6760.

15 a) Vondung, L.; Frank, N.; Fritz, M.; Alig, L.; Langer, R. Phosphine-Stabilized Borylenes and Boryl Anions as Ligands? Redox Reactivity in Boron-Based Pincer Complexes. Angew. Chem. Int. Ed. 2016, 55, 14450-14454; b) Maser, L.; Vondung, L.; Langer, R. The $\mathrm{ABC}$ in pincer chemistry - From amine- to borylene- and carbon-based pincer-ligands. Polyhedron 2018, 143, 28-42.

16 For recent related reviews and related articles on this topic see: a) Owen, G. R. Functional group migrations between boron and metal centres within transition metal-borane and - 
boryl complexes and cleavage of $\mathrm{H}-\mathrm{H}, \mathrm{E}-\mathrm{H}$ and E-E' bonds. Chem. Commun. 2016, 52 , 10712-10726; b) Kameo, H.; Nakazawa, H. Recent Developments in the Coordination Chemistry of Multidentate Ligands Featuring a Boron Moiety. Chem. Asian J. 2013, 8, 1720-1734; c) Owen, G. R. Hydrogen atom storage upon Z-class borane ligand functions: an alternative approach to ligand cooperation. Chem. Soc. Rev. 2012, 41, 3535-3546. d) Owen, G. R. Crystal field arguments to explain the trans labilisation within transition metal-borane complexes. Trans. Met. Chem. 2010, 35, 221-228; e) Bouhadir, G.; Bourissou, D. Complexes of ambiphilic ligands: reactivity and catalytic applications. Chem. Soc. Rev. 2016, 45, 1065-1079; f) Devillard, M.; Bouhadir, G.; Bourissou, D. Cooperation between Transition Metals and Lewis Acids: A Way To Activate $\mathrm{H}_{2}$ and H-E bonds. Angew. Chem. Int. Ed. 2015, 54, 730-732; g) Amgoune, A.; Bouhadir, G.; Bourissou, D. Reactions of phosphine-boranes and related frustrated Lewis pairs with transition metal complexes. Top. Curr. Chem. 2013, 334, 281-311; h) Amgoune, A.; Bourissou, D. A new insight into ortho-(dimesitylboryl)diphenylphosphines: applications in Pd-catalyzed Suzuki-Miyaura couplings and evidence for secondary $\pi$-interaction. Chem. Commun. 2011, 47, 8163-8165; i) Bouchadir, G.; Amgoune, A.; Bourissou, D. Phosphine-Boranes and Related Ambiphilic Compounds: Synthesis, Structure, and Coordination to Transition Metals. Adv. Organomet. Chem. 2010, 58, 1-107; j) Maity, A.; Teets, T. S. Main Group Lewis Acid-Mediated Transformations of Transition-Metal Hydride Complexes. Chem. Rev. 2016, 116, 8873-8911.

17 For examples of platinum complexes featuring both borane and boryl ligands see: a) Borner, C.; Kleeberg, C. Selective Synthesis of Unsymmetrical Diboryl $\mathrm{Pt}^{\mathrm{II}}$ and Diaminoboryl $\mathrm{Cu}^{\mathrm{I}}$ Complexes by B-B Activation of Unsymmetrical Diboranes(4) \{pinB- 
$\left.\mathrm{B}\left[(\mathrm{NR})_{2} \mathrm{C}_{6} \mathrm{H}_{4}\right]\right\}$. Eur. J. Inorg. Chem. 2014, 2486-2489; b) Braunschweig, H.; Brenner, P.; Dewhurst, R. D.; Guethlein, F.; Jimenez-Halla, J. O. C.; Radacki, K.; Wolf, J.; Zöllner, L. Observation of Elementary Steps in the Catalytic Borane Dehydrocoupling Reaction. Chem. Eur. J. 2012, 18, 8605-8609; c) Braunschweig, H.; Damme, A.; Kupfer, T. Conversion of trans-Diboran(4)yl Platinum Complexes into Their cis-Bisboryl Analogues. Chem. Eur. J. 2013, 19, 14682-14686; d) Schubert, H.; Leis, W.; Mayer, H. A.; Wesemann, L. A bidentate boryl ligand: syntheses of platinum and iridium complexes. Chem. Commun. 2014, 50, 2738-2740; e) Schindler, T.; Lux, M.; Peters, M.; Scharf, L. T.; Osseili, H.; Maron L.; Tauchert, M. E. Synthesis and Reactivity of Palladium Complexes Featuring a Diphosphinoborane Ligand. Organometallics 2015, 34, 1978-1984; f) Cowie, B. E.; Emslie, D. J. H. Platinum Complexes of a Borane-Appended Analogue of 1,1'Bis(diphenylphosphino)ferrocene: Flexible Borane Coordination Modes and in situ Vinylborane Formation. Chem. Eur. J. 2014, 20, 16899-16912.

18 a) Tsoureas, N.; Owen, G. R.; Hamilton, A.; Orpen, A. G. Flexible scorpionates for transfer hydrogenation: the first example of their catalytic application. Dalton Trans. 2008, 60396044; b) van der Vulgt, J. I. Boryl-Based Pincer Systems: New Avenues in Boron Chemistry. Angew. Chem. Int. Ed. 2010, 49, 252-255; c) Zeng, G.; Sakaki, S. Unexpected Electronic Process of $\mathrm{H}_{2}$ Activation by a New Nickel Borane Complex: Comparison with the Usual Homolytic and Heterolytic Activations. Inorg. Chem. 2013, 52, 2844-2853; d) Li, Y.; Hou, C.; Jiang, J.; Zhang, Z.; Zhao, C.; Page, A. J.; Ke, Z. General $\mathrm{H}_{2}$ Activation Modes for Lewis Acid-Transition Metal Bifunctional Catalysts. ACS. Cat. 2016, 6, 16551662. 
19 a) Annibale, V. T.; Song, D. Multidentate actor ligands as versatile platforms for small molecule activation and catalysis. $R S C A d v .2013,3,11432-11449$; b) Barrett, B. J.; Iluc, V. M. Metal-ligand cooperation between palladium and a diphosphine ligand with an olefinic backbone. Inorg. Chim. Acta 2017, 460, 35-42; c) Barnett, B. R.; Neville, M. L.; Moore, C. E.; Rheingold A. L.; Figueroa, J. S. Oxidative-Insertion Reactivity Across a Geometrically Constrained Metal $\rightarrow$ Borane Interaction. Angew. Chem. Int. Ed. 2017, 56, 7195-7199.

20 Devillard, M.; Bouhadir, G.; Bourissou, D. Cooperation between Transition Metals and Lewis Acids: A Way To Activate $\mathrm{H}_{2}$ and $\mathrm{H}-\mathrm{E}$ bonds. Angew. Chem. Int. Ed. 2015, 54, 730732.

21 a) Tsoureas, N.; Kuo, Y.-Y.; Haddow, M. F.; Owen, G. R. Double addition of $\mathrm{H}_{2}$ to transition metal-borane complexes: a 'hydride shuttle' process between boron and transition metal centres. Chem. Commun. 2011, 47, 484-486; b) Suess, D. L. M.; Tsay, C.; Peters, J. C. Dihydrogen Binding to Isostructural $\mathrm{S}=1 / 2$ and $\mathrm{S}=0$ Cobalt Complexes. $J$. Am. Chem. Soc. 2012, 134, 14158-14164.

22 Hill, A. F.; Owen, G. R.; White, A. J. P.; Williams, D. J. The Sting of the Scorpion: A Metallaboratrane. Angew. Chem., Int. Ed. 1999, 38, 2759-2761.

23 Crossley, I. R.; Hill, A. F.; Willis, A. C. Unlocking the metallaboratrane cage: reversible B-H activation in platinaboratranes. Dalton Trans. 2008, 201-203.

24 Very recently, Neshat, Shahsavari and Mastrorilli have provided a second example of reversible hydride migration from a borohydride functional group to form a metal-hydride and Z-type borane ligand, see reference 12 . 
25 See for example: a) Del Castillo, T. J.; Thompson, N. B.; Suess, D. L. M.; Ung G.; Peters, J. C. Evaluating Molecular Cobalt Complexes for the Conversion of $\mathrm{N}_{2}$ to $\mathrm{NH}_{3}$. Inorg. Chem. 2015, 54, 9256-9262; b) Gunderson, W. A.; Suess, D. L. M.; Fong, H.; Wang, X.; Hoffmann, C. M.; Cutsail III, G. E.; Peters J. C.; Hoffman, B. M. Free $\mathrm{H}_{2}$ Rotation vs JahnTeller Constraints in the Nonclassical Trigonal (TPB)Co- $\mathrm{H}_{2}$ Complex. J. Am. Chem. Soc. 2014, 136, 14998-15009.

26 a) Dyson, G.; Hamilton, A.; Mitchell, B.; Owen, G. R. A new family of flexible scorpionate ligands based on 2-mercaptopyridine. Dalton Trans. 2009, 6120-6126; b) Owen, G. R.; Gould, P. H.; Hamilton, A.; Tsoureas, N. Unexpected pincer-type coordination ( $\left.\kappa^{3}-\mathrm{SBS}\right)$ within a zerovalent platinum metallaboratrane complex. Dalton Trans. 2010, 39, 49-52; c) Owen, G. R.; Gould, P. H.; Charmant, J. P. H.; Hamilton, A.; Saithong, S. A new hybrid scorpionate ligand: a study of the metal-boron bond within metallaboratrane complexes. Dalton Trans. 2010, 39, 392-400; d) Dyson, G; Zech, A.; Rawe, B. W.; Haddow, M. F.; Hamilton, A.; Owen, G. R. Scorpionate Ligands Based on 2-Mercaptopyridine: A Ligand with a Greater Propensity To Sting? Organometallics 2011, 30, 5844-5850; e) Iannetelli, A.; Tizzard, G.; Coles S. J.; and Owen, G. R. Sequential Migrations between Boron and Rhodium Centers: A Cooperative Process between Rhodium and a Monosubstituted Borohydride Unit. Inorg. Chem. 2018, 57, 446-456.

27 a) Naktode, K.; Reddy, Th. D. N.; Nayek, H. P.; Mallik, B. S.; Panda, T. K. Heavier group 2 metal complexes with a flexible scorpionate ligand based on 2-mercaptopyridine. RSC Adv. 2015, 5, 51413-51420; b) Saha, K.; Ramalakshmi, R.; Gomosta, S.; Pathak, K.; Dorcet, V.; Roisnel, T.; Halet, J.-F.; Ghosh, S. Design, Synthesis, and Chemistry of Bis $(\sigma)$ borate and Agostic Complexes of Group 7 Metals. Chem. Eur. J. 2017, 23, 9812- 
9820; c) Saha, K.; Ramalakshmi, R.; Borthakur, R.; Gomosta, S.; Pathak, K.; Dorcet, V.; Roisnel, T.; Halet J.-F.; Ghosh, S. An Efficient Method for the Synthesis of Boratrane Complexes of Late Transition Metals. Chem. Eur. J. 2017, 23, 18264-18275.

28 a) Roy, D. K.; De, A.; Panda, S.; Varghese B.; Ghosh, S. Chemistry of N,S-Heterocyclic Carbene and Metallaboratrane Complexes: A New $\eta^{3}$-BCC-Borataallyl Complex. Chem. Eur. J. 2015, 21, 13732 - 13738; b) Anju, R. S.; Roy, D. K.; Mondal, B.; Yuvaraj, K.; Arivazhagan, C.; Saha, K.; Varghese B.; Ghosh, S. Reactivity of Diruthenium and Dirhodium Analogues of Pentaborane(9): Agostic versus Boratrane Complexes. Angew. Chem. Int. Ed. 2014, 53, 2873-2877; c) Crossley, I. R.; Hill A. F.; Willis, A. C. Formation of Metallaboratranes: The Missing Link. The First Iridaboratranes, $\left[\operatorname{IrH}(\mathrm{CO})\left(\mathrm{PPh}_{3}\right)\left\{\kappa^{3}-\right.\right.$ $\left.\left.\mathrm{B}, \mathrm{S}, \mathrm{S}^{`}-\mathrm{B}(\mathrm{mt})_{2} \mathrm{R}\right\}\right](\mathrm{Ir} \rightarrow \mathrm{B})(\mathrm{mt}=$ Methimazolyl, $\mathrm{R}=\mathrm{mt}, \mathrm{H})$. Organometallics 2005, 24, 1062-1064.

29 a) Chatt, J.; Vallarino, L. M.; Venanzi, L. M. Olefin co-ordination compounds. Part IV. Diene complexes of platinum(II). The structure of Hofmann and von Narbutt's [dicyclopentadiene(RO)PtCl]. J. Chem. Soc. 1957, 2496-2505; b) Wylie, W. N. O; Lough, A. J.; Morris, R. H. Palladium(II) and Platinum(II) Complexes Featuring a NitrileFunctionalized N-Heterocyclic Carbene Ligand. Organometallics 2010, 29, 570-581; c) Boyer, J. L.; Cundari, T. R.; DeYonker, N. J.; Rauchfuss, T. B.; Wilson, S. R. Redox Activation of Alkene Ligands in Platinum Complexes with Non-innocent Ligands. Inorg. Chem. 2009, 48, 638-645; d) Ghavale, N.; Dey, S.; Jain, V. K. Tewari, R. 2Methoxycycloocta-1,5-dienyl platinum complexes as precursors for platinum nanoparticles. Bull. Mater. Sci., 2009, 32, 15-18. 
30 The ${ }^{31} \mathrm{P}\left\{{ }^{1} \mathrm{H}\right\}$ NMR of the reaction mixture did not show any clear signal, not even that for free phosphine at $-62 \mathrm{ppm}$. There may be a very broad signal in the baseline which could indicate a weak interaction of the phosphine with the complex, perhaps trans to the quadrupolar boron center in $\mathbf{P t}_{\text {int. }}$

31 A solid was isolated from this reaction however it was found to be unstable and it decomposed in a somewhat slower but similar fashion to that observed for the phosphine free reaction.

32 Crossley, I. R.; Hill, A. F. Di- and Zerovalent Platinaboratranes: The First Pentacoordinate $\mathrm{d}^{10}$ Platinum(0) Complex. Organometallics 2004, 23, 5656-5658.

33 If the $\left[\mathrm{H}_{2} \mathrm{~B}(\mathrm{mp})_{2}\right]$ ligand had been transformed to $\left[\mathrm{HB}(\mathrm{mp})_{2}\right]$ then a doublet resonance would have been expected in the corresponding ${ }^{11} \mathrm{~B}$ NMR experiment. Unfortunately, the signal was too broad (h.h.w. $=420 \mathrm{~Hz}$ ) to observed any ${ }^{1} \mathrm{~J}_{\mathrm{BH}}$ coupling.

34 We originally suggested in reference 14, that the identity of $\mathbf{P t}_{\text {int }}$ was $\left[\mathrm{Pt}\left\{\kappa^{3}-S, S, H\right.\right.$ $\left.\left.\mathrm{H}_{2} \mathrm{~B}(\mathrm{mp})_{2}\right\}\left\{\mathrm{COE}^{\mathrm{OMe}}\right\}\right]$ since we did not observe a platinum-hydride in our preliminary investigations. We now have clear evidence of a $\mathrm{Pt}-\mathrm{H}$ species. This, in addition to the large ${ }^{1} \mathrm{~J}_{\mathrm{PtB}}$ coupling constant provides clear evidence of the transfer of hydride from borohydride to metal center and that $\mathbf{P t}$ int is $\left[\mathrm{PtH}\left\{\kappa^{3}-S, B, S-\mathrm{HB}(\mathrm{mp})_{2}\right\}\left\{\eta^{2}-\mathrm{COE}^{\mathrm{OMe}}\right\}\right]$.

35 a) Chatt, J., Vallarino, L. M.; Venanzi, L. N. Olefin co-ordination compounds. Part V. Some diene complexes of palladium(II) and their alkoxy-derivatives. J. Chem. Soc. 1957, 34133416; b) Bailey, C. T.; Lisensky, G. C. Synthesis of organometallic palladium complexes: An undergraduate experiment. J. Chem. Edu. 1985, 62, 896-897; c) Bianchini, C.; Meli, A.; Oberhauser, W.; Segarra, A. M.; Passaglia, E.; Lamač, M.; Štěpnička, P. The Reactions 
of Silver, Zirconium, and Hafnium Fluorides with Liquid Ammonia: Syntheses and Crystal Structures of $\mathrm{Ag}\left(\mathrm{NH}_{3}\right)_{2} \mathrm{~F} \cdot 2 \mathrm{NH}_{3}$, $\left[\mathrm{M}\left(\mathrm{NH}_{3}\right)_{4} \mathrm{~F}_{4}\right] \cdot \mathrm{NH}_{3}\left(\mathrm{M}=\mathrm{Zr}\right.$, Hf), and $\left(\mathrm{N}_{2} \mathrm{H}_{7}\right) \mathrm{F}$. Eur. $J$. Inorg. Chem. 2008, 441-447; d) Hoel, G. R.; Stockland Jr., R. A.; Anderson, G. K.; Ladipo, F. T.; Braddock-Wilking, J.; Rath, N. P.; Mareque-Rivas, J. C. Nucleophilic Attack on Cyclooctadiene Complexes of Palladium: Stereochemistry of the Resulting Cyclooctenylpalladium Derivatives. Organometallics 1998, 17, 1155-1165.

36 Crossley, I. R.; Hayes, J. Bis(methimazolyl)borate chemistry of palladium and platinum. J. Organomet. Chem. 2012, 716, 285-288.

37 Pal, S.; Drover, M. W.; Patrick, B. O.; Love, J. A. Enhancing Reactivity of Directly Observable B-H-Pt Interactions through Conformational Rigidity. Eur. J. Inorg. Chem. 2016, 2403-2408.

38 We were not able to locate a reported example of ${ }^{2} \mathrm{~J}_{\mathrm{PtH}}$ coupling involving a $\mathrm{Pt}-\mathrm{B}(\mathrm{H})$ unit. For a closely related example involving a Pt- $\mathrm{C}(\mathrm{H})$ unit see: Roselló-Merino, M.; Rama, R. J.; Díezb, J.; Conejero, S. Catalytic dehydrocoupling of amine-boranes and amines into diaminoboranes: isolation of a Pt(II), Shimoi-type, $\eta^{1}-\mathrm{BH}$ complex. Chem. Commun. 2016, $52,8389-8392$.

39 Kaur, P.; Brownless, A.; Perera, S. D.; Cooke, P. A.; Jelínek, T.; Kennedy, J. D.; Štíbr, B.; Thornton-Pett, M. Macropolyhedral boron-containing cluster chemistry. $\left[\mathrm{PtMe}_{2}\left(\mathrm{PMe}_{2} \mathrm{Ph}\right)_{2}\right]$ as a cluster metallating agent. Isolation and characterisation of nineteen-vertex $\quad\left[\left(\mathrm{PMe}_{2} \mathrm{Ph}\right) \mathrm{HPt}-\eta^{4}\right.$-syn- $\left.\mathrm{B}_{18} \mathrm{H}_{19}\left(\mathrm{PMe}_{2} \mathrm{Ph}\right)\right] \quad$ and eighteen-vertex $\left[\left(\mathrm{PMe}_{2} \mathrm{Ph}\right)_{2} \mathrm{PtS}_{2} \mathrm{~B}_{15} \mathrm{H}_{14}(\mathrm{NHCOMe})\right.$. J. Organomet. Chem. 1998, 557, 181-185. 
40 Groom, C. R.; Bruno, I. J.; Lightfoot, M. P.; Ward, S. C. The Cambridge Structural Database. Acta Cryst. 2016, B72, 171-179.

41 One of the three structures within the asymmetric unit for complex $\mathbf{1 0}$ contains an interaction of the $\mathrm{BH}$ unit with a toluene solvent molecule. In this complex the $\mathrm{Pd}(1)-\mathrm{B}(1)$ distance is $2.19(2) \AA$. This value has not been included in the range provided since the distance is impacted by the solvent interaction.

42 A search of the Cambridge Structural Database (April 2018) revealed 335 examples of Pt$\mathrm{PCy}_{3}$ bonds. The Pt-P distances ranged from $2.210 \AA$ to $2.3970 \AA$. Of those compounds that feature longer bond distances, the phosphorus ligand is trans to a ligand which is well known to be of high trans influence, a boryl fragment or a species acting as an Z-type ligands. See for example: a) Curtis, D.; Lesley, M. J. G.; Norman, N. C.; Orpen, A. G.; Starbuck, J. Phosphine exchange reactions involving cis- $\left[\mathrm{Pt}\left(\mathrm{PPh}_{3}\right)_{2}(\mathrm{Bcat})_{2}\right](\mathrm{cat}=1,2-$ $\left.\mathrm{O}_{2} \mathrm{C}_{6} \mathrm{H}_{4}\right)$ and the oxidative addition of $1,2-\mathrm{B}_{2} \mathrm{Cl}_{2}\left(\mathrm{NMe}_{2}\right)_{2}$ to $\mathrm{Pt}^{0}$. J. Chem. Soc., Dalton Trans., 1999, 1687-1694; b) Bertermann, R.; Böhnke, J.; Braunschweig, H.; Dewhurst, R. D.; Kupfer, T.; Muessig, J. H.; Pentecost, L.; Radacki, K.; Sen, S. S.; Vargas, A. Dynamic, Reversible Oxidative Addition of Highly Polar Bonds to a Transition Metal. J. Am. Chem. Soc. 2016 138, 16140-16147; c) Braunschweig, H.; Damme, A. Thermodynamic control of oxidative addition and reductive elimination processes in cis-bis(dimethoxyboryl)bis(tricyclohexylphosphine)platinum(II). Chem. Commun. 2013, 49, 5216-5218; d) Braunschweig, H.; Dewhurst, R. D.; Hupp, F.; Wolf, J. Unprecedented Oxidative Addition and Metal-Only Lewis Pair Chemistry of Antimony Trihalides. Chem. Eur. J. 2015, 21, 1860 - 1862; e) Braunschweig, H.; Bertermann, R.; Brenner, P.; Burzler, M.; Dewhurst, R. D.; Radacki, K.; Seeler, F. trans-[Pt(BCat' $\left.) \mathrm{Me}\left(\mathrm{PCy}_{3}\right)_{2}\right]$ : An Experimental Case Study 
of Reductive Elimination Processes in Pt-Boryls through Associative Mechanisms. Chem. Eur. J. 2011, 17, $11828-11837$.

43 a) Zhao, X.; Otten, E.; Song, D.; Stephan, D. W. Ni $\rightarrow$ B Interactions in Nickel PhosphinoAlkynyl-Borane Complexes. Chem. Eur. J. 2010, 16, 2040-2044; b) Crossley, I. R.; Hill, A. F.; Willis, A. C. Metallaboratranes: Tris(methimazolyl)borane Complexes of Rhodium(I). Organometallics 2006, 25, 289-299; c) Fontaine, F.G.; Boudreau, J.; Thibault, M-H. Coordination Chemistry of Neutral $\left(\mathrm{L}_{\mathrm{n}}\right)-\mathrm{Z}$ Amphoteric and Ambiphilic Ligands. Eur. J. Inorg. Chem. 2008, 5439-5454.

44 Mizuta, T.; Tanaka, N.; Iwakuni, Y.; Kubo, K.; Miyoshi, K. Synthesis and Reactivity of Five-Membered P(V)-Phosphapalladacycles. Organometallics 2009, 28, 2808-2817.

45 Tolman, C. A. Steric effects of phosphorus ligands in organometallic chemistry and homogeneous catalysis. Chem. Rev. 1977, 77, 313-348.

46 a) Clark, H.C.; Manzer, L. E. Reactions of ( $\pi-1,5$-cyclooctadiene) organoplatinum(II) compounds and the synthesis of perfluoroalkylplatinum complexes. J. Organomet. Chem. 1973, 59, 411-428; b) Rulke, R. E.; Ernsting, J. M.; Spek, A. L.; Elsevier, C. J.; van Leeuwen, P. W. N. M.; Vrieze K. NMR study on the coordination behavior of dissymmetric terdentate trinitrogen ligands on methylpalladium(II) compounds. Inorg. Chem. 1993, 32, 5769-5778.

47 Lam, E.; Farrar, D. H.; Browning, C. S.; Lough, A. J. Reactions of 2-indolylphosphines with $\mathrm{Ru}_{3}(\mathrm{CO})_{12}$ : cluster capping with $\mu_{3}, \eta^{2}$-indolylphosphine as an anionic six-electron P,N-donor ligand. Dalton Trans., 2004, 3383-3388. 
48 Overlapping peaks in the aromatic region of the ${ }^{1} \mathrm{H}$ NMR spectra were assigned with the aid of 2D NMR spectra $\left({ }^{1} \mathrm{H}-{ }^{1} \mathrm{H}\right.$ COSY, ${ }^{1} \mathrm{H}_{-}{ }^{13} \mathrm{H}$ HSQC and ${ }^{1} \mathrm{H}-{ }^{13} \mathrm{C}$ HMBC). This has allowed for the assignment of the environment's chemical shift but is unable to afford the multiplicity and any accompanying coupling constants.

49 Coles, S. J.; Gale, P. A. Changing and challenging times for service crystallography. Chem. Sci. 2012, 3, 683-689.

50 CrysAlisPro Software System, Rigaku Oxford Diffraction, 2015.

51 Sheldrick, G.M. Crystal structure refinement with ShelXL, Acta Cryst. 2015, C27, 3-8.

52 Sheldrick, G. M. SHELXT - Integrated space-group and crystal structure determination. Acta Cryst. 2015, A71, 3-8.

53 Dolomanov, O. V.; Bourhis, L. J.; Gildea, R.J.; Howard, J.A.K.; Puschmann, H. OLEX2: a complete structure solution, refinement and analysis program. J. Appl. Cryst. 2009, 42, 339-341.

\section{ASSOCIATED CONTENT}

The following files are available free of charge.

Crystallographic parameters, selected distances and angles for all crystal structures in addition to selected spectroscopic data are provided in the Electronic Supporting Information.

\section{AUTHOR INFORMATION}

\section{Corresponding Author}

* Dr. Gareth R. Owen, School of Applied Science, University of South Wales, Treforest, United Kingdom, CF37 1DL, E-mail: gareth.owen@southwales.ac.uk 


\section{Author Contributions}

The manuscript was written through contributions of all authors. All authors have given approval to the final version of the manuscript. The authors declare no competing financial interest.

\section{Acknowledgements}

The authors would like to thank the Leverhulme Trust (PRG-2015-097) for funding (GRO). The project is also part funded by the FLEXIS research project (WEFO 80835). We are also very grateful to the EPSRC UK National Mass Spectrometry Facility (NMSF) at Swansea University.

\section{Graphical Abstract}

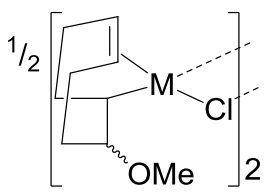

$\mathrm{PR}_{3}, \mathrm{Na}\left[\mathrm{H}_{2} \mathrm{~B}(\mathrm{mp})_{2}\right]$

$\mathrm{M}=\mathrm{Pd}, \mathrm{Pt}$

Synthesis of secondary borane pincers

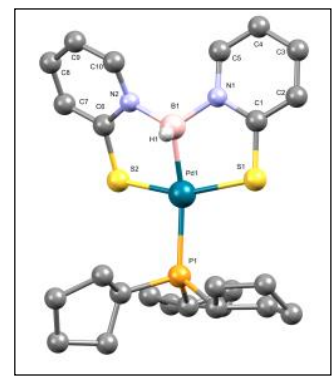

A general method for the synthesis of palladium and platinum pincer complexes containing a $\kappa^{3}$ $S, B, S$ coordinated $\mathrm{HB}(\mathrm{mp})_{2}$ ligand (where $\mathrm{mp}$ - 2-mercaptopyridyl) is presented providing a rare set of pincer complexes containing a secondary borane functional group as the central species. 